NBER WORKING PAPER SERIES

\title{
THE EFFECT OF EDUCATION AND SCHOOL QUALITY ON FEMALE CRIME
}

\author{
Javier Cano-Urbina \\ Lance Lochner \\ Working Paper 24061 \\ http://www.nber.org/papers/w24061
}

\author{
NATIONAL BUREAU OF ECONOMIC RESEARCH \\ 1050 Massachusetts Avenue \\ Cambridge, MA 02138 \\ November 2017
}

For valuable comments, we thank Rodrigo Soares, Steve Machin, participants at the CESifo Area Conference on Economics of Education, and seminar participants from the University of Pennsylvania Criminology Department and Institute of Education Sciences. We also thank Jeffrey Lingwall and Mel Stephens for providing us with measures of school quality for an extended history. Lochner thanks the Social Sciences and Humanities Research Council of Canada for financial support. The views expressed herein are those of the authors and do not necessarily reflect the views of the National Bureau of Economic Research.

NBER working papers are circulated for discussion and comment purposes. They have not been peer-reviewed or been subject to the review by the NBER Board of Directors that accompanies official NBER publications.

(C) 2017 by Javier Cano-Urbina and Lance Lochner. All rights reserved. Short sections of text, not to exceed two paragraphs, may be quoted without explicit permission provided that full credit, including ( $)$ notice, is given to the source. 
The Effect of Education and School Quality on Female Crime

Javier Cano-Urbina and Lance Lochner

NBER Working Paper No. 24061

November 2017

JEL No. H75,I22,K42

\begin{abstract}
$\underline{\text { ABSTRACT }}$
This paper estimates the effects of educational attainment and school quality on crime among American women. Using changes in compulsory schooling laws as instruments, we estimate significant effects of schooling attainment on the probability of incarceration using Census data from 1960-1980. Using data from the 1960-90 Uniform Crime Reports, we also estimate that increases in average schooling levels reduce arrest rates for violent and property crime but not white collar crime. Our results suggest small and mixed direct effects of school quality (as measured by pupil-teacher ratios, term length, and teacher salaries) on incarceration and arrests. Finally, we show that the effects of education on crime for women are unlikely to be due to changes in labor market opportunities and may be more related to changes in marital opportunities and family formation.
\end{abstract}

Javier Cano-Urbina

Department of Economics

Florida State University

113 Collegiate Loop

Tallahassee, FL 32306

jcanourbina@fsu.edu

Lance Lochner

Department of Economics, Faculty of Social Science

Western University

1151 Richmond Street, North

London, ON N6A 5C2

CANADA

and NBER

llochner@uwo.ca 


\title{
The Effect of Education and School Quality on Female Crime*
}

\author{
Javier Cano-Urbina ${ }^{\dagger}$ and Lance Lochner ${ }^{\ddagger}$
}

October 22, 2017

\begin{abstract}
This paper estimates the effects of educational attainment and school quality on crime among American women. Using changes in compulsory schooling laws as instruments, we estimate significant effects of schooling attainment on the probability of incarceration using Census data from 1960-1980. Using data from the 1960-90 Uniform Crime Reports, we also estimate that increases in average schooling levels reduce arrest rates for violent and property crime but not white collar crime. Our results suggest small and mixed direct effects of school quality (as measured by pupil-teacher ratios, term length, and teacher salaries) on incarceration and arrests. Finally, we show that the effects of education on crime for women are unlikely to be due to changes in labor market opportunities and may be more related to changes in marital opportunities and family formation.
\end{abstract}

\section{Introduction}

Historically, men have committed crime at much higher rates than women. As a result, most research on the determinants of and trends in crime has focused on men. Yet, the share of female arrests has increased significantly in the U.S. over the past few decades with women

\footnotetext{
${ }^{*}$ For valuable comments, we thank Rodrigo Soares, Steve Machin, participants at the CESifo Area Conference on Economics of Education, and seminar participants from the University of Pennsylvania Criminology Department and Institute of Education Sciences. We also thank Jeffrey Lingwall and Mel Stephens for providing us with measures of school quality for an extended history.

${ }^{\dagger}$ Department of Economics, The Florida State University. 113 Collegiate Loop, 257 Bellamy Building, Tallahassee, Florida 32306. E-mail: jcanourbina@fsu.edu.

${ }^{\ddagger}$ Department of Economics, University of Western Ontario. 1151 Richmond Street, 4022 Social Science Centre, London, Ontario, N6A 5C2, Canada. E-mail: llochner@uwo.ca.
} 
now accounting for more than one-third of all arrests for both property and white collar offenses and roughly one-fifth of arrests for violent offenses ${ }^{1}$

Given these trends, it is becoming increasingly important to understand the determinants of crime among women as well as men, especially factors that may be influenced by policy $\left.\right|^{2}$ This paper studies the extent to which education policies and schooling attainment discourage criminal activity among women. Most sociological theories of crime (e.g. strain, conflict, labeling, control theories) as well as economic theories based on human capital and rational choice (Becker, 1968; Ehrlich, 1975; Freeman, 1996; Lochner, 2004) suggest that human capital investments should reduce (most types of) crime, and there is growing evidence from the U.S. and other developed countries that this is the case. However, nearly all of this evidence is based on studies of men.$^{3}$ While Hjalmarsson et al. (2015) and Machin et al. (2011) attempt to estimate the causal effects of educational attainment on crime for women as well as men, the estimated effects for women in both studies are very imprecise. $4^{4}$

There are many reasons to think that the impacts of education on crime may differ between men and women. To begin, the nature of many criminal offenses differs by gender: crime tends to be of a more personal nature for women. For example, female homicides are often perpetrated against their husbands or partners (Steffensmeier and Streifel, 1992; Schwartz and Steffensmeier, 2007). This suggests that the extent to which schooling influences family structure may be particularly important for women. Additionally, women participate much less in the labor market and are more involved in household production than men, so their opportunity costs of crime likely differ. On the one hand, the lower employment rates by women suggest that the wage returns to education may be less relevant to their decisions to engage in crime. On the other hand, women typically have higher labor supply elasticities than men (Blundell and MaCurdy, 1999) $!^{5}$ Women's traditional role as

\footnotetext{
${ }^{1}$ In 1980, the final year for much of our analysis, women accounted for $36 \%$ of arrests for white collar crime, $21 \%$ of arrests for property crime, and $10 \%$ of arrests for violent crime. Violent crimes refer to murder and non-negligent manslaughter, robbery, and aggravated assault; property offenses include burglary, larcenytheft, motor vehicle theft, and arson; white collar crimes include forgery and counterfeiting, fraud, and embezzlement. Statistics from 1980 are from Schwartz and Steffensmeier (2007), while more recent statistics are from the FBI's Uniform Crime Reports.

${ }^{2}$ See Steffensmeier and Streifel (1992), Schwartz and Steffensmeier (2007), and Engelhardt et al. (2008) for discussions of the underlying causes for increased criminal activity by women.

${ }^{3}$ See Lochner (2010, 2011) and Hjalmarsson and Lochner (2012) for recent surveys.

${ }^{4}$ Both studies estimate statistically insignificant effects of education on female crime with large standard errors relative to the impacts one might expect given rates of female offending. In the case of Hjalmarsson et al. (2015), the Swedish schooling reforms they study had much weaker effects on female education levels, so their instrumental variable is not as powerful for studying female crime. This is not the case for the increase in the minimum schooling age in the U.K. studied by Machin et al. (2011). In this study, standard errors are quite large relative to baseline crime rates among women but not men.

5 Lochner and Moretti (2004) argue that the increase in wages associated with education can explain most of the impacts of education on crime for men.
} 
secondary earners in families suggests that education's impact on their marital prospects may be important if family resources are an important determinant of crime. Similarly, women's traditional role as primary child caregivers (especially in single-parent homes) means that any effects of schooling on fertility may also be important if the presence of children factors into decisions to engage in criminal activity (e.g. stronger incentives to avoid incarceration). We consider some of these possible channels through which education may affect female crime.

Anyone familiar with Gary Becker's seminal contributions on human capital Becker, 1964), crime (Becker, 1968), and the family (Becker, 1991) will immediately see the fingerprints of his work throughout our analysis. To both guide and interpret our empirical approach, we develop a simple econometric framework based on many of the insights of his research and that which has followed. In particular, we consider the possibility that schooling affects female crime through higher wages, as women compare the tradeoff between spending time in legitimate work vs. criminal activity (including potential time incarcerated). Schooling may also impact crime by raising household income (through higher wages and its impacts on work), which may alter both the costs and benefits of crime. Importantly, household income depends not only on women's own earnings but also that of their husbands - more educated women are likely to marry more educated, and higher earning, men due to positive assortative mating. Marriage itself may also indirectly impact crime through fertility choices, as well as directly through the incentives to avoid prison or the efficient allocation of time within the household. Finally, we recognize that a change in education policies should not only affect a woman's crime rate through changes in her own schooling, but it might also affect her decision to marry (and whom to marry) through equilibrium adjustments in marriage markets, since changes in policy affect the entire distributions of male and female schooling. Equilibrium changes in marriage matching functions can introduce challenges in using compulsory schooling laws as instruments for educational attainment. We discuss the likely bias introduced by these equilibrium adjustments and develop strategies to both quantify and alleviate their impacts.

Estimating the causal effect of education on crime is difficult, because factors not observed by the researcher may determine both schooling choices and criminal behavior. For example, individuals with self-control problems or who discount the future heavily may perform poorly in school or place little value on the long-run returns to education, and they may also be more likely to engage in crime. Lochner and Moretti (2004) address these endogeneity problems by using changes in state-level compulsory schooling laws over time as instrumental variables (IV) to estimate the causal effect of educational attainment on the probability of incarceration and arrest rates for American men. Their estimates reveal 
that an additional year of schooling reduces the probability of incarceration by slightly more than 0.1 percentage points for white men and 0.4 percentage points for black men. These reflect $10-15 \%$ reductions relative to baseline incarceration rates for high school dropouts. An additional year of average schooling levels in a state reduces arrest rates by $11 \%$ or more. Other recent studies taking a similar estimation approach reach similar conclusions for men in Sweden (Hjalmarsson et al., 2015) and the United Kingdom (Machin et al., 2011) 6

A few studies suggest that improvements in school quality may lead to reductions in criminal activity during early adulthood. For example, using randomized school admission lotteries, Cullen et al. (2006) and Deming (2011) find that students who 'win' the opportunity to attend better-performing public schools commit less crime during school and the first few years after leaving school. Weiner et al. (2009) show that desegregation initiatives in some U.S. states led to substantial improvements in school quality for blacks. Among blacks experiencing desegregation, high school graduation rates increased by a few percentage points and homicide arrest rates declined by one-third at ages 15-19. Little is known about the longer run impacts of school quality on crime, and there are no studies that examine the effects of more direct measures of quality. $]^{7}$

Our empirical analysis begins by estimating the effects of state-level compulsory schooling laws and direct measures of elementary and secondary school quality (pupil-teacher ratios, school term length, and teacher wage rates) on female incarceration and arrest rates throughout adulthood. These results suggest that education policies during childhood and adolescence can serve as criminal deterrents later in life. To understand why, we examine the effects of these policies on educational attainment, family structure, work behavior, and family earnings. Consistent with prior research, we observe substantial impacts of mandatory schooling laws and school quality on educational attainment among women. Our estimates also suggest very small (mostly insignificant) impacts on a woman's own work behavior but moderate impacts on marriage, spousal earnings, and fertility behavior. Thus, schooling policy (and educational attainment) are most likely to impact female crime rates through family structure rather than the tradeoff between work and crime that appears to be important for men.

\footnotetext{
${ }^{6}$ Studying more recent American male cohorts, Bell et al. (2016) find weaker effects of compulsory schooling laws on educational attainment (especially for white men) but statistically significant impacts on arrests and incarceration.

${ }^{7}$ Evidence on the effects of state-level school quality measures on earnings is mixed (Card and Krueger 1992a Heckman et al., 1996, Hanushek, 2002). In their analysis of state-level school quality on earnings, Heckman et al. (1996) argue that interactions between region of birth and region of residence are important to account for selective migration and the possibility that skills acquired by attending school in one region may not be rewarded equally in other regions of the country. Although these forces are less likely to be important for our analysis of criminal behavior, we also consider specifications that account for these interaction effects.
} 
Assuming that the impacts of schooling laws on female crime derive from changes in female education levels, we simultaneously estimate the effects of educational attainment and school quality on female incarceration and arrest rates using changes in compulsory schooling laws as instruments for attainment 8 In examining the impacts of school quality, we consider both the direct effects holding schooling attainment constant as well as the indirect effects through increases in attainment. By simultaneously considering the impacts of attainment and quality, we address important concerns raised by Stephens and Yang (2014) that increases in compulsory schooling laws are correlated with improvements in school quality in the U.S.9

Based on U.S. Census data from 1960, 1970 and 1980, our IV estimates suggest that an additional year of schooling reduces incarceration rates by $0.04-0.08$ percentage points for white and black women. These estimates are largely unaffected by controls for school quality. Notably, we also estimate significant (though smaller) effects of schooling on incarceration when we control (and instrument) for marital status. The direct effects of quality improvements on incarceration are relatively small and mixed, while the indirect effects of quality through increased schooling attainment are mostly positive and modest in size.

A similar picture emerges when we estimate the effects of schooling attainment and quality on state-level arrest rates for women using data from the 1960, 1970, 1980 and 1990 Federal Bureau of Investigation's Uniform Crime Reports (UCR). Regardless of whether we control for school quality, our IV estimates suggest significant effects of educational attainment on arrest rates for violent and property crime but not white collar crime. By contrast, school quality improvements have mixed (direct) effects on state-level female arrest rates.

This paper proceeds as follows. Section 2 discusses the economics of schooling, marriage and crime, developing a simple econometric framework that guides and aids in interpreting our empirical analysis. In particular, we discuss several channels through which education policy and schooling may affect criminal behavior. We also discuss the conditions under which IV estimates can identify the total effect of education on crime when the instruments may impact marriage markets and marital sorting. Section 3 describes the Census and UCR data used in our empirical analysis, along with our state- and cohort-level measures of compulsory schooling laws and school quality. The main contribution of this paper is contained in Sections 4 and 5. Section 4 empirically studies the effects of state-level schooling laws and

\footnotetext{
${ }^{8}$ We assume throughout that both schooling laws and school quality levels are exogenous with respect to subsequent female crime. See Lochner and Moretti (2004) for evidence on the former and footnote 7 for concerns raised in related studies on the impacts of state-level school quality measures on earnings.

${ }^{9}$ We also consider specifications that account for region-specific cohort trends as suggested by Stephens and Yang (2014).
} 
quality on female incarceration and arrest rates. This section also shows how these education policies affect educational attainment, marriage and family structure, employment, and earnings. In Section 5, we estimate the effects of educational attainment and school quality on female incarceration and arrest rates, using compulsory schooling laws as instruments for attainment. Section 6 briefly discusses the channels through which schooling likely affects female crime. We summarize our findings and offer concluding thoughts in Section 7.

\section{The Economics of Schooling, Marriage and Crime - a Simple Econometric Framework}

This section develops an econometric framework for estimating the effects of schooling policy and educational attainment on female crime. This framework incorporates several important channels by which policies and education may impact crime, with particular attention paid to the role of marriage. While our empirical analysis will assume linear relationships between key variables, we take a more general approach here.

Suppose a woman's crime rate $c$ depends on whether she is married $(m=1)$ or single $(m=0)$, her wages $w$, total family income $Y$, schooling attainment $s$, school quality $Q$, and an idiosyncratic random shock $\varepsilon$ :

$$
c=C^{m}(w, Y, s, Q)+\varepsilon
$$

Assume that women's wages $w(s, Q)$ and earnings $y(s, Q)$ are strictly increasing in their schooling attainment and school quality 10 Educational attainment depends on schooling laws $L$, school quality $Q$, and an idiosyncratic shock $\eta$ :

$$
s=S(L, Q)+\eta
$$

where $S(L, Q)$ is strictly increasing in both $L$ and $Q$.

To reflect the fact that education policies affect the entire distributions of educational attainment for men and women, and therefore, marriage markets, let $\theta(L, Q)$ represent a statistic for the joint schooling distribution for men and women (e.g. relative average education levels) that determines sorting in marriage matching markets. This 'matching statistic' $\theta$ can impact both the probability of marriage and the educational attainment of matched spouses. For expositional purposes, we assume that a single statistic defines all matches;

\footnotetext{
${ }^{10}$ For simplicity, we abstract from shocks to wages and earnings; however, it is straightforward (though a bit cumbersome) to incorporate both.
} 
however, it is straightforward to allow for an entire vector of statistics. Marriage decisions and spousal education $\tilde{s}$ depend on a woman's own schooling as well as marriage markets:

$$
\begin{aligned}
m & =1\left(m^{*}<0\right) \\
m^{*} & =M(s, \theta(L, Q))-\xi \\
\tilde{s} & =\tilde{S}(s, \theta(L, Q)) .
\end{aligned}
$$

Total household income includes the woman's and her spouse's income (if married):

$$
Y=y(s, Q)+m \cdot \tilde{y}(\tilde{s}, Q)
$$

where spousal income $\tilde{y}(\tilde{s}, Q)$ depends on school quality $Q$ and is strictly increasing in the spouse's education $\tilde{s}$. We assume that all shocks are mean zero and independent of both policy variables, $(\varepsilon, \eta, \xi) \Perp(L, Q)$. In this sense, the policy variables $(L, Q)$ are exogenous. ${ }^{11}$

While we do not explicitly model fertility behavior, which may be influenced by education policies and affect crime, it should enter the problem in a qualitatively similar way to that of wages or family income, since the number of children in the household is likely to be impacted by schooling attainment, school quality, and marital status. 12 Incorporating the number of children in the household would not alter our main points and discussion below, except to add an additional channel through which education and education policies may affect crime.

The marginal impact of additional schooling on crime for women with schooling $s$ under laws $L$ and quality $Q$ depends on their marital status $m \in\{0,1\}$ :

$$
\beta^{m}(s, L, Q) \equiv \frac{d c}{d s}=\frac{\partial C^{m}}{\partial w} \frac{\partial w}{\partial s}+\frac{\partial C^{m}}{\partial Y} \frac{\partial y}{\partial s}+m\left(\frac{\partial C^{m}}{\partial Y} \frac{\partial \tilde{y}}{\partial \tilde{s}} \frac{\partial \tilde{S}}{\partial s}\right)+\frac{\partial C^{m}}{\partial s}
$$

This includes 'substitution effects' of schooling through higher wages, 'income effects' through higher family income, and 'direct effects' of schooling on crime. For married women, it includes an additional income effect that derives from a different match in the marriage market 13 In the standard economic model of crime, in which committing crime or incarceration

\footnotetext{
${ }^{11}$ It is straightforward to condition the entire analysis on any additional exogenous characteristics; however, we refrain from doing so here to simplify the exposition.

${ }^{12}$ This does not necessarily mean that an increase in the number of children in the household would have the same effects (or even effects of the same sign) as increases in wages or family income. Instead, we claim that the expressions related to wages and family income in the equations that follow could apply equally to the number of children in the household.

${ }^{13}$ For single women, schooling laws only affect crime through schooling, so the the marginal effect of additional schooling on their crime does not depend on $L$, i.e. $\beta^{0}(s, L, Q)=\beta^{0}(s, Q)$.
} 
as punishment for crime requires time out of the labor market, higher wages reduce crime (Ehrlich, 1975; Grogger, 1998; Freeman, 1999; Lochner, 2004). Empirical studies confirm this relationship (Grogger, 1998; Gould et al., 2002; Machin and Meghir, 2004). It is also commonly thought that higher family income leads to less crime; however, the evidence is largely inconclusive or mixed ${ }^{14}$ The direct effects of schooling on crime may reflect any impacts of education on preferences (for risk, time discounting, self-control, or sociability) that may alter incentives to engage in crime.

A standard regression of crime on schooling attainment will produce inconsistent estimates of $\beta^{m}(s, L, Q)$ if $\varepsilon$ is not independent of $s$ conditional on $(L, Q)$. Among single women, schooling laws only affect crime indirectly through schooling attainment, suggesting that they may serve as valid instruments. This is not necessarily the case for married women, since schooling policies may also affect their crime directly through impacts on the distribution of schooling and marital matching functions if $\frac{\partial \tilde{S}}{\partial \theta}$ and $\frac{\partial \theta}{\partial L}$ are non-zero. To see this, notice that the 'reduced form' effects of schooling laws on crime are given by

$$
\frac{d c}{d L}=\beta^{m}(s, L, Q) \frac{\partial S}{\partial L}+m\left(\frac{\partial C^{m}}{\partial Y} \frac{\partial \tilde{y}}{\partial \tilde{s}} \frac{\partial \tilde{S}}{\partial \theta} \frac{\partial \theta}{\partial L}\right), \quad m \in\{0,1\}
$$

Dividing this by $\partial S / \partial L$ yields

$$
\frac{d c / d L}{\partial S / \partial L}=\beta^{m}(s, L, Q)+m\left(\frac{\partial C^{m}}{\partial Y} \frac{\partial \tilde{y}}{\partial \tilde{s}} \frac{\partial \tilde{S}}{\partial \theta} \frac{\partial \theta}{\partial L} / \frac{\partial S}{\partial L}\right), \quad m \in\{0,1\}
$$

If $E(\varepsilon \mid L, Q, m=0)=0$, an IV approach (using schooling laws as instruments for schooling attainment) should yield consistent estimates of the average total effect of education on crime for the sample of unmarried women. For married women, the second term in equation (2) reflects the impacts of changes in marital sorting (i.e. spousal education conditional on own educational attainment) due to adjustments in the marriage market. These equilibrium effects can lead to inconsistent IV estimation of the causal effect of education on crime unless either: (i) income effects on crime are zero (for married women), $\frac{\partial C^{1}}{\partial Y}=0$, or (ii) changes in schooling laws do not alter spousal schooling levels except through changes in women's own schooling, $\frac{\partial \tilde{S}}{\partial \theta} \frac{\partial \theta}{\partial L}=0.16$ If either of these conditions holds and $E(\varepsilon \mid L, Q, m=1)=0$, then an

\footnotetext{
${ }^{14}$ See Tittle et al. $(1978)$ for an influential early meta analysis of the effects of social class on crime. More recently, Heller et al. (2011) provide a survey of the (mostly economics) literature on the effects of family income on crime, focusing primarily on adolescents and young adults.

${ }^{15}$ Appendix B presents analogous 'reduced-form' effects of school quality on crime.

${ }^{16}$ We have implicitly assumed that spousal education only impacts crime through household income; however, it is possible that a more educated spouse could exert other positive influences on behavior. This would also lead to bias unless schooling laws had no effect on marriage matching functions.
} 
IV approach should yield consistent estimates of the average total effect of education on crime for married women. (See Appendix B for additional details.) It is important to note that our exogeneity assumption $\varepsilon \Perp(L, Q)$ does not necessarily imply that $E(\varepsilon \mid L, Q, m)=0$, in which case any selection introduced by conditioning on marital status would need to be addressed 17 Below, we consider a control function approach.

Finally, consider average crime among all women regardless of their marital status. Letting $P(s, L, Q)$ reflect the probability a woman with schooling level $s$ under laws $L$ and quality $Q$ is married, the total effect of an increase in own schooling on expected crime is

$\bar{\beta}(s, L, Q) \equiv \frac{d E[c \mid s, L, Q]}{d s}=[1-P(s, L, Q)] \beta^{0}(s, L, Q)+P(s, L, Q) \beta^{1}(s, L, Q)+\frac{\partial P}{\partial s} \Delta(w, Y, s, Q)$, where $\Delta(w, Y, s, Q) \equiv C^{1}(w, Y, s, Q)-C^{0}(w, Y, s, Q)$ is the effect of marriage on crime. (See Appendix $\mathrm{B}$ for further details.) In addition to a weighted average of the effects on single and married women, schooling also impacts expected crime rates through its impact on the probability of marriage.

As described in Appendix B, using schooling laws as instruments for educational attainment in the full sample of women has two potential sources of bias: (i) changes in the matching function can impact which type of man any given woman might marry conditional on her educational attainment, (ii) changes in the marriage matching function might affect whether women decide to marry at all (conditional on their education). If family income and marriage both reduce crime and increased mandatory schooling raises marriage rates and improves the education distribution of spouses, then estimated (negative) effects of ownschooling on crime are likely to be exaggerated when using schooling laws as instruments.

It is worth noting that even large effects of schooling laws on male and female education levels need not impact marital matching functions. For example, if the ratio of male to female education (e.g. high school graduate rates) determines the likelihood of finding a spouse and the education of that spouse, then an increase in compulsory schooling laws that proportionally impacted male and female education levels would have no effect on marital matching functions. In this case, women who increase their education would match with more educated men and, perhaps, marry at higher rates as a result, but there would be no effect on marriage rates and matches for women who did not adjust their schooling. This would not create any bias for IV estimation of $\bar{\beta}(s, L, Q)$, since the impacts of schooling laws would come entirely through adjustments in women's own schooling attainment.

Appendix B presents a special case in which marriage has no direct effect on crime. In

\footnotetext{
${ }^{17}$ If marriage shocks are independent of crime shocks conditional on schooling laws and quality, $\xi \Perp$ $\varepsilon \mid(L, Q)$, then $E(\varepsilon \mid L, Q, m)=0$.
} 
this special case, if crime is non-increasing in wages, household income, and schooling, then a negative IV estimate implies that $\bar{\beta}(s, L, Q)<0$, since negative effects from higher spousal income must be accompanied by negative effects of higher own income. In this case, we can bound the extent to which any marital matching effects bias our estimates if there is positive assortative mating.

Altogether, this simple framework suggests that when marriage matching functions are affected by the schooling law instruments, IV estimates of the effects of crime are likely to be biased towards finding too strong an effect. In some cases, it is possible to bound the extent of the bias. Better still, one can estimate the effects of schooling (and school quality) separately by marital status, while addressing concerns about selection into marriage. Alternatively, one could simply control (and instrument) for marital status along with schooling and school quality. It is useful to remember, however, that these solutions will produce estimated effects of education that omit any impacts that come through changes in marital status.

\section{Data}

This section provides a brief description of the data and samples used in our empirical analysis. (See Appendix A for further details.) Similar data on incarceration, arrests, educational attainment, and compulsory schooling laws (for men) are used in Lochner and Moretti (2004). Data on school quality from Card and Krueger (1992a) (extended by Stephens and Yang (2014)) are also incorporated.

\subsection{Census Data on Incarceration, Education, Family, Work, and Earnings}

We use individual-level data from the 1960, 1970, and 1980 US Censuses to study the link between education policy and female incarceration rates. Appendix Table $\mathrm{A}-1$ presents descriptive statistics for key variables in our sample of 20-60 year-old women from the US Censuses. Over the 1960-80 period, about .02 percent of white women and .1-.15 percent of black women were in prison at the time of the Censuses. Average education increased by 1.6 years for whites and 2.8 years for blacks.

Table 1 presents the unconditional relationship between schooling and female incarceration in the Census data. Female incarceration rates are typically more than twice as high for high school dropouts as for those who finished high school. Incarceration rates are lowest for college graduates. Figure1 1 indicates that the relationship between schooling attainment and incarceration conditional on individual characteristics (age, state of birth, state of residence, 
Table 1: Census Incarceration Rates for Women (in Percent)

\begin{tabular}{ccccc}
\hline \hline & All Years & 1960 & 1970 & 1980 \\
\hline White women & & & & \\
HS dropouts & 0.04 & 0.03 & 0.03 & 0.05 \\
HS graduates & 0.02 & 0.01 & 0.01 & 0.02 \\
Some college & 0.02 & 0.01 & 0.01 & 0.02 \\
College + & 0.00 & 0.00 & 0.00 & 0.01 \\
Black women & & & & \\
HS dropouts & 0.20 & 0.17 & 0.15 & 0.22 \\
HS graduates & 0.09 & 0.04 & 0.05 & 0.10 \\
Some college & 0.11 & 0.04 & 0.04 & 0.12 \\
College + & 0.06 & 0.00 & 0.00 & 0.07 \\
\hline
\end{tabular}

Notes: 'HS dropouts' completed less than 12 years of schooling, 'HS graduates' completed exactly 12 years of schooling, 'Some college' completed 13-15 years of schooling, and 'College +' completed at least 16 years of schooling.

cohort of birth, and year) is negative over most grades with particularly strong drops in incarceration associated with high school completion.

We also use a number of other variables available in the Censuses to study key channels through which education policy and education may affect crime. To measure impacts of education and education policy on family structure, we use women's marital status at the time of the survey, as well as their husband's educational attainment. For women ages 20-40, we use the total number of their own children in the household as a measure of fertility. ${ }^{18}$ We also create an indicator for teen motherhood using the oldest child's year of birth less the mother's year of birth. Since we only know this for children residing in the household, we limit our analysis of teen motherhood to women ages 20-35. To measure effects on work decisions, we use weeks worked last year and create an indicator variable for whether women were employed in the previous year (i.e. positive weeks worked) 19 The Census data also contain measures of pre-tax earnings in the previous year for both respondents and their spouses.

\subsection{Compulsory Schooling Laws and School Quality Measures}

Both compulsory schooling attendance laws and school quality have been shown to affect educational attainment and subsequent earnings Acemoglu and Angrist, 2001; Card and

\begin{tabular}{l}
\hline${ }^{18}$ We limit our analysis of this variable to ages $20-40$ in an effort to best capture total fertility to date, \\
since very few women have children after age 40 and most children should still be living with their parents \\
up to that point. Less than 1 percent of women report 9 or more children, which are topcoded as having 9. \\
\hline \hline${ }^{19}$ For 1960 and 1970, weeks worked was only reported in intervals. We use the midpoint of these categories.
\end{tabular}


Figure 1: Probability of incarceration by years of schooling conditional on age, state of birth, state of residence, cohort of birth, and year

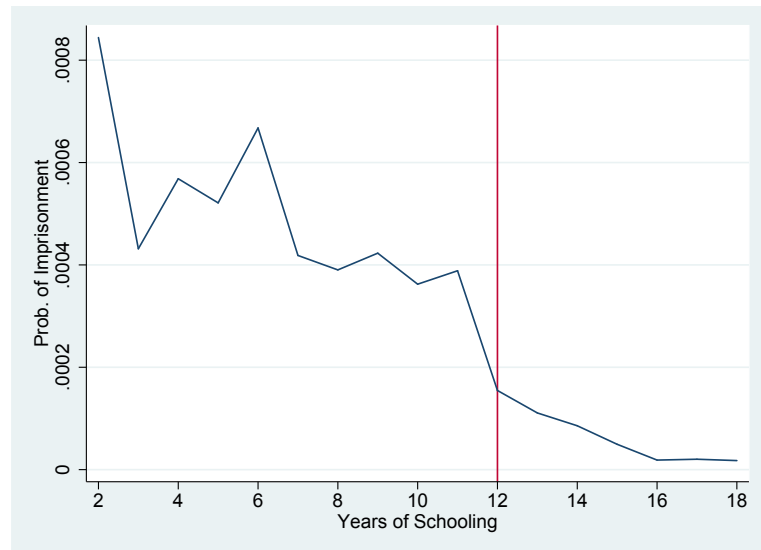

(a) White Females

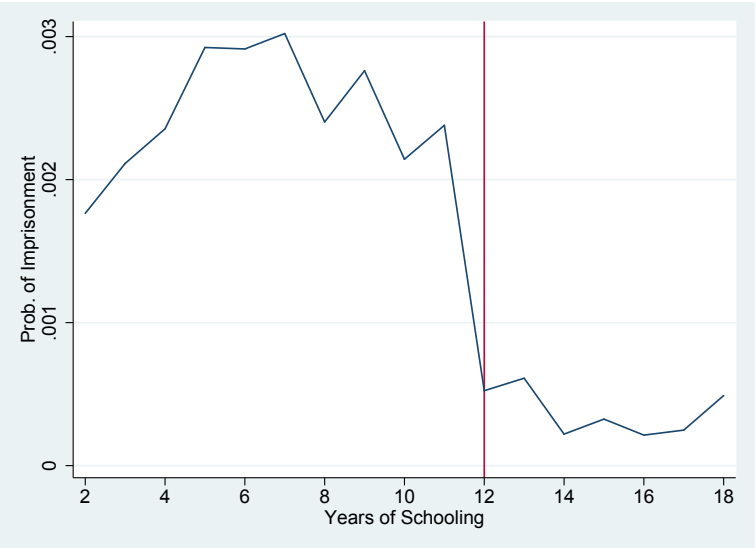

(b) Black Females

Notes: Regression-adjusted probability of incarceration is obtained from a regression of an indicator for incarceration on indicators for state of residence, state of birth (excluding Alaska and Hawaii), age (ages 20-22, 23-25, .., 56-58, and 59-60), decade of birth (1914-1923, 1924-1933, .., 19641974 ), and year. Results based on sample of women ages 20-60 in 1960, 1970, and 1980 U.S. Censuses. The sample size for white females is 3,613,313 and for black females is 480,709.

Krueger, 1992a). We use state-year level data on these education policy variables to calculate the laws and quality measures that applied during the relevant ages for women in our Census samples. We briefly describe these measures here and refer the reader to Appendix A for further details.

Compulsory schooling laws typically require that youth attend school for a given number of years or specify the ages at which youth must start and can end their schooling. Following Acemoglu and Angrist (2001) and Lochner and Moretti (2004), we combine these laws to create three indicator variables reflecting the minimum number of required years of schooling: 9 years, 10 years, and 11 or more years. These indicators are created for individuals based on the laws that applied (in their state of birth) when they were 14 years old. Table 2 reports the fraction of women in our sample who experienced different compulsory schooling laws. As demonstrated in the table, compulsory schooling ages generally increased over time; however, Lochner and Moretti (2004) show that there is considerable cross-state variation in the time patterns for these laws, with some states even relaxing compulsory schooling laws during some periods.

Our analysis considers three measures of school quality from Card and Krueger (1992a) and extended by Stephens and Yang (2014): (i) pupil/teacher ratios, (ii) school term lengths, and (iii) average teacher salaries ${ }^{20}$ In calculating each school quality measure for an indi-

\footnotetext{
${ }^{20}$ The authors are grateful to Melvin Stephens Jr. and Jeff Lingwall for sharing these data.
} 
Table 2: Fraction of Women Facing Different Compulsory Schooling Laws by Census Year

\begin{tabular}{|c|c|c|c|c|c|c|}
\hline \multirow[b]{2}{*}{ Compulsory Attendance } & \multicolumn{3}{|c|}{ White Females } & \multicolumn{3}{|c|}{ Black Females } \\
\hline & 1960 & 1970 & 1980 & 1960 & 1970 & 1980 \\
\hline \multirow[t]{2}{*}{$\leq 8$ years } & 0.310 & 0.200 & 0.145 & 0.480 & 0.280 & 0.175 \\
\hline & $(0.462)$ & $(0.400)$ & $(0.352)$ & $(0.500)$ & $(0.449)$ & $(0.380)$ \\
\hline \multirow[t]{2}{*}{$=9$ years } & 0.449 & 0.457 & 0.405 & 0.341 & 0.439 & 0.450 \\
\hline & $(0.497)$ & $(0.498)$ & $(0.491)$ & $(0.474)$ & $(0.496)$ & $(0.497)$ \\
\hline \multirow[t]{2}{*}{$=10$ years } & 0.065 & 0.070 & 0.098 & 0.081 & 0.079 & 0.099 \\
\hline & $(0.247)$ & $(0.256)$ & $(0.297)$ & $(0.272)$ & $(0.270)$ & $(0.298)$ \\
\hline$\geq 11$ years & $\begin{array}{c}0.177 \\
(0.381)\end{array}$ & $\begin{array}{c}0.273 \\
(0.446)\end{array}$ & $\begin{array}{c}0.353 \\
(0.478)\end{array}$ & $\begin{array}{c}0.098 \\
(0.298)\end{array}$ & $\begin{array}{c}0.202 \\
(0.402)\end{array}$ & $\begin{array}{c}0.277 \\
(0.447)\end{array}$ \\
\hline Sample size & 366,070 & 807,787 & $2,439,456$ & 43,452 & 96,745 & 340,512 \\
\hline
\end{tabular}

Notes: Table reports mean (standard deviation) for indicators of different compulsory schooling requirements based on state of birth and year individuals were age 14. Results based on sample of women ages 20-60 in 1960, 1970 and 1980 U.S. Censuses.

Table 3: School Quality Measures by Census Year for White Women

\begin{tabular}{lccc}
\hline \hline Variable & 1960 & 1970 & 1980 \\
\hline Pupil/Teacher ratio (10's of students) & 2.943 & 2.776 & 2.536 \\
& $(0.479)$ & $(0.424)$ & $(0.386)$ \\
Term length (100's of days) & 1.729 & 1.754 & 1.774 \\
& $(0.127)$ & $(0.097)$ & $(0.059)$ \\
Relative teacher wage & 1.061 & 1.050 & 1.030 \\
& $(0.253)$ & $(0.222)$ & $(0.181)$ \\
Sample size & 333,816 & 807,787 & $2,354,186$ \\
\hline Notes: Table reports mean (standard deviation) for school quality mea- \\
sures based on sample of white women ages 20-60 in 1960, 1970, and \\
1980 U.S. Censuses. Pupil-teacher ratios reported in 10s of students per \\
teacher. Term length reported in 100s of days. Relative teacher wage re- \\
flects the state average salary for teachers divided by the national average \\
of all state averages of teacher salary.
\end{tabular}

vidual, we use the average value in their state of birth over ages 6 to 17 . Since state-level quality measures are not very reflective of the quality of schools attended by blacks from most of the cohorts we study (Card and Krueger, 1992b), we limit our attention to white women whenever we consider school quality measures. For expositional purposes, we have scaled these measures so pupil/teacher ratios reflect 10s of pupils per teacher, term lengths are in 100s of days, and relative teacher salary reflects state average teacher salary divided by a measure of national average teacher salary. The evolution of these measures over time for our sample of white women is reported in Table 3.

Stephens and Yang (2014) raise concerns about previous studies that have used compulsory schooling laws as instruments for education without accounting for accompanying 
Table 4: Conditional Correlation between Schooling Laws and School Quality Measures for White Women

\begin{tabular}{lcccc}
\hline \hline & $\begin{array}{c}\text { Years of } \\
\text { Comp. Attend. }\end{array}$ & $\begin{array}{c}\text { Pupil/Teacher } \\
\text { ratio }\end{array}$ & $\begin{array}{c}\text { Term } \\
\text { length }\end{array}$ & $\begin{array}{c}\text { Relative } \\
\text { teacher wage }\end{array}$ \\
\hline Years of Compulsory Attendance & 1.00 & - & - & - \\
Pupil/Teacher ratio & -0.10 & 1.00 & - & - \\
Term length & 0.08 & -0.32 & 1.00 & - \\
Relative teacher wage & 0.14 & 0.05 & 0.37 & 1.00 \\
\hline
\end{tabular}

Notes: Table reports correlations between residuals from regressions of reported schooling laws and quality measures on indicators for state of residence, state of birth (excluding Alaska and Hawaii), age (ages 20-22, 23-25, .., 56-58, and 59-60), decade of birth (1914-1923, 1924-1933, .., 1964-1974), year, state of residence $\times$ year, and state of residence $\times$ age. Results based on sample of white women ages 20-60 in 1960, 1970, and 1980 U.S. Censuses.

changes in school quality. A strong correlation between these policy variables over time would likely be problematic. To explore this issue in our context, we examine the correlation between schooling laws and school quality after conditioning on other regressors in our empirical analyses. Specifically, Table 4 reports the correlation between residuals obtained from regressions of years of compulsory schooling and our school quality measures on the main covariates in our empirical analyses below: state of residence, state of birth, age, cohort of birth, year, state of residence-specific year effects, and state of residence-specific age effects. The first column shows quite small correlations (-0.10 to 0.14) between the minimum required years of schooling for an individual and all three school quality measures.

Table 4 also documents the correlations between our three school quality measures. These range from -0.32 (for term length and pupil-teacher ratio) to 0.37 (term length and relative teacher wage). Interestingly, the correlation between teacher wages and pupil-teacher ratios of 0.05 suggests that class sizes grow slightly when teacher wages increase. Quality does not necessarily improve in all dimensions at the same time. In fact, there is considerable independent variation in all three quality measures.

\subsection{UCR Data on State-Level Arrests}

The Census data do not allow us to distinguish between different types of criminal offenses. We, therefore, turn to the 1960, 1970, 1980, and 1990 FBI's Uniform Crime Reports (UCR) for data on female arrests by age, state, year, and criminal offense. We consider violent (murder and non-negligent manslaughter, robbery, and aggravated assault), property (burglarybreaking or entering, larceny-theft, motor vehicle theft, and arson), and white collar (forgery and counterfeiting, fraud, and embezzlement) offenses. Arrest counts for women ages 20-59 broken into five-year age groups are merged with Census data to obtain age-specific arrest 
rates by state, year, and offense. As discussed in Appendix A, we also use Census data to calculate the fraction of women under different compulsory schooling regimes, average school quality levels, average educational attainment, and the fraction of women that are black by corresponding age group, state, and year.

\section{The Effects of Education Policy on Crime and Vari- ous Determinants}

We begin our empirical analysis by examining the effects compulsory schooling laws and school quality on the probability of incarceration and state-level arrest rates. Our analysis of incarceration is based on Census data and is at the individual level, while the latter is based on UCR arrest rates measured at the state-age-year level. We then return to the Census data to examine several of the channels through which education policies may affect female crime based on Section 2. Most importantly, we examine the effects of schooling laws and quality on educational attainment. These specifications effectively serve as firststage results in our IV analysis of the effects of schooling attainment and quality on crime reported in Section5. We also examine the effects of schooling policy on marriage and family structure, as well as work, and earnings. Throughout our empirical analysis, we estimate linear specifications, which can be viewed as approximations to the more general functions employed in Section 2,

Our estimating equations using 1960, 1970, and 1980 Census data will all be of a similar form:

$$
O_{i t}=L_{i t}^{\prime} \alpha_{L}+Q_{i t}^{\prime} \alpha_{Q}+X_{i t}^{\prime} \alpha_{X}+\epsilon_{i t}^{O}
$$

where $O_{i t}$ is the outcome of interest for individual $i$ observed in year $t ; L_{i t}$ is a vector of compulsory schooling law indicators; $Q_{i t}$ is a vector of school quality measures; and $X_{i t}$ is a vector of observed covariates that always includes indicator variables for state of residence, state of birth, age (ages 20-22, 23-25,...,56-58, and 59-60), decade of birth (1914-1923, 1924$1933, \ldots, 1964-1974)$, and Census year ${ }^{21}$ Importantly, most specifications control for state-ofresidence-specific year effects, which account for differences across states over time in terms of their law enforcement and criminal justice policies, as well as labor market conditions. Motivated by the analysis of Stephens and Yang (2014), we also consider a specification that controls for region-of-birth-specific cohort trends. An alternative set of specifications

\footnotetext{
${ }^{21}$ See Section 3 for a detailed description of the schooling laws and quality measures for each individual. For black females, the covariates also include state-of-birth dummies interacted with a dummy for black women born in the South who turn age 14 in 1958 or later to account for the impact of Brown v. Board of Education.
} 
controls for state-of-residence-specific age patterns to account for any differences in policies toward younger vs. older offenders. Unless otherwise noted, our sample includes women ages 20-60 at the time of the Census. Given the differences in incarceration by race, we perform separate analyses for black and white women. As noted earlier, we limit our analysis to white women when we explore the role of school quality.

Our analysis of arrest rates is based on a similar specification; however, the UCR data only contain arrests by state, age group, and year for 10 offense types. We, merge UCR data on female arrests from 1960, 1970, 1980, and 1990 with the corresponding U.S. Censuses to study the impacts of education policies on female arrest rates for property, violent, and white collar offenses. (See Section 3 and Appendix A for greater detail.) The basic relationship we estimate using these data is:

$$
\ln \left(A_{\text {calt }}\right)=L_{\text {alt }}^{\prime} \beta_{L}+Q_{\text {alt }}^{\prime} \beta_{Q}+X_{\text {calt }}^{\prime} \beta_{X}+\epsilon_{\text {calt }}^{A}
$$

where $\ln \left(A_{\text {calt }}\right)$ is the natural logarithm of the female arrest rate for offense $c$, five-year age group $a$, in state $l$, in year $t ; L_{\text {alt }}$ and $Q_{\text {alt }}$ reflect the fraction of women facing different compulsory schooling laws and average school quality measures based on age group $a$ in state $l$ for year $t$ (based on Census data). Covariates $X_{\text {calt }}$ include the proportion of women that are black in age group $a$ in state $l$ in year $t$ obtained from the Census, as well as several indicator variables to control for unobserved heterogeneity across states, age groups, criminal offenses, and years. Most notably, we include state $\times$ year indicators (and state $\times$ year $\times$ offense indicators) to account for variation in enforcement policies across states and over time (by offense type). Offense-specific age indicators account for well-documented differences in age profiles by offense type, while age-specific year and state indicators allow for systematic variation in age-crime profiles over time and across states.

An important distinction between our UCR-based arrest and Census-based incarceration analyses is the unit of observation. Our UCR analysis uses state-level averages (rather than individual-level measures) for arrests and schooling policies. Since our individual-based analysis of incarceration enables us to distinguish between state of birth and state of current residence, we can freely control for age- and year-specific effects by state of residence while still exploiting variation in compulsory schooling ages across cohorts and states of birth. This is not possible with our aggregated analysis using the UCR data. Instead, this analysis computes measures of compulsory schooling ages and school quality levels that applied to residents in each state $l$ from age group $a$ in year $t$ based on those residents' state and year of birth. Thus, our schooling law measures $L_{\text {alt }}$ now represent the fractions of individuals in age group $a$ living in state $l$ in year $t$ that were born in states that had compulsory 
schooling ages of 9, 10, and 11 or more when they were age 1422 School quality measures are calculated in an analogous way. (See Appendix A for details.) Because the policies only vary at the state-cohort level, it is not possible to simultaneously control for unrestricted state-age and state-year effects due to multicollinearity. To flexibly account for different enforcement policies across states over time, we control for state-year effects; however, we are then only able to control for broad age group (i.e. ages 20-34, 35-49, 50-60) effects by state.

\subsection{Incarceration and Arrests}

We begin by estimating equation (3) using an indicator for imprisonment at the time of the Census as the dependent variable, reporting estimated effects in percentage terms (i.e. coefficients multiplied by 100) ${ }^{23}$ Appendix Table D-2 (online) reports the estimated effects of compulsory schooling laws (when omitting school quality measures) on the probability of incarceration separately for white and black women. Unfortunately, the estimates for blacks are imprecise due to their smaller sample size, so we focus our discussion on results for white women. Unexpectedly, the point estimates for white women suggest that requiring at least 9 years of schooling (insignificantly) increases the probability of incarceration by .002.004 percentage points relative to requiring 8 or fewer years; however, requiring at least 11 years of schooling reduces the incarceration probability by about .01-.013 percentage points relative to a 9-year requirement 24 Among white women, simultaneously controlling for both compulsory schooling laws and school quality produces very similar effects of the schooling laws as reported in Table 5. Notably, none of the school quality measures are statistically significant (individually or collectively) in any specification.

Turning to the UCR data on arrests, Table 6 reports estimates of equation (4). The first three columns report results for all arrests using different sets of covariates. Unlike our Census results for incarceration, school quality rather than compulsory schooling laws appear to have greater effects on arrest rates. While compulsory schooling of at least 11 years significantly reduces arrest rates (by around 20\%) in columns 1 and 2, we cannot reject that all minimum schooling laws together have no effect based on standard F-tests. All school quality measures (individually and collectively) have statistically significant impacts on arrest rates; however, not all suggest that quality improvements are crime-reducing. Adding 10 days to the school

\footnotetext{
${ }^{22}$ This approach improves on that of Lochner and Moretti (2004), who use compulsory schooling laws that applied in state $l$ when the mid-point of age group $a$ in year $t$ was age 14 . The approach taken in this paper accounts for cross-state migration patterns and yields more powerful instruments.

${ }^{23}$ All standard errors account for state of birth-year of birth clustering.

${ }^{24}$ The latter reflects the difference between the coefficients on 'Compulsory attendance $\geq 11$ ' and 'Compulsory attendance $=9^{\prime}$.
} 
Table 5: Effects of Compulsory Schooling Laws and School Quality on Imprisonment for White Women (in Percentage Terms)

\begin{tabular}{lccccc}
\hline \hline & $(1)$ & $(2)$ & $(3)$ & $(4)$ & $(5)$ \\
\hline Compulsory attendance $=9$ & 0.003 & 0.003 & $0.008^{* *}$ & 0.005 & 0.005 \\
& $(0.003)$ & $(0.003)$ & $(0.004)$ & $(0.004)$ & $(0.003)$ \\
Compulsory attendance $=10$ & -0.004 & -0.004 & -0.001 & -0.003 & -0.001 \\
& $(0.004)$ & $(0.004)$ & $(0.004)$ & $(0.004)$ & $(0.004)$ \\
Compulsory attendance $\geq 11$ & $-0.010^{* *}$ & $-0.009^{* *}$ & -0.004 & -0.005 & -0.005 \\
& $(0.004)$ & $(0.004)$ & $(0.004)$ & $(0.004)$ & $(0.004)$ \\
Pupil/Teacher ratio (10's of students) & 0.008 & $0.011^{*}$ & 0.010 & 0.010 & 0.006 \\
& $(0.006)$ & $(0.006)$ & $(0.007)$ & $(0.007)$ & $(0.008)$ \\
Term length (100's of days) & -0.016 & -0.012 & -0.030 & -0.030 & -0.032 \\
& $(0.019)$ & $(0.020)$ & $(0.025)$ & $(0.024)$ & $(0.024)$ \\
Relative teacher wage & 0.007 & 0.006 & 0.005 & 0.007 & 0.000 \\
& $(0.007)$ & $(0.007)$ & $(0.008)$ & $(0.008)$ & $(0.008)$ \\
& & & & & \\
F-statistic for no CSL effects & 5.54 & 4.45 & 3.71 & 2.88 & 2.87 \\
(p-value) & $(0.00)$ & $(0.00)$ & $(0.01)$ & $(0.03)$ & $(0.03)$ \\
F-statistic for no school quality effects & 1.55 & 1.76 & 1.50 & 1.71 & 0.94 \\
(p-value) & $(0.20)$ & $(0.15)$ & $(0.21)$ & $(0.16)$ & $(0.42)$ \\
& & & & & \\
Additional controls: & & & & & $\mathrm{y}$ \\
State of residence $\times$ year effects & & & & & $\mathrm{y}$ \\
State of residence $\times$ age & & & & & $\mathrm{y}$ \\
State of residence $\times$ broad age group & & & & & $\mathrm{y}$ \\
Region of birth $\times$ cohort trend & & & & & \\
\hline
\end{tabular}

Notes: All regressions include dummies for state of residence, dummies for state of birth (excluding Alaska and Hawaii), dummies for age groups (age 20-22, 23-25, ..., 56-58, and 59-60), dummies for decade of birth (1914-1923, 1924-1933, .., 1964-1974), and dummies for census year. "broad age group" reflects three dummies for the following age groups: 20-34, 35-49, and 50-64. F-stastics are reported separately for tests of zero effects of all three compulsory attendance measures and for zero effects for all three school quality measures. The sample size for is $3,495,789$. Standard errors corrected for state of birth-year of birth clustering are in parentheses. ${ }^{* *}$ p-value $<0.05$. ${ }^{*}$ p-value $<0.10$. 
year reduces subsequent female arrest rates by 8-14\%, and increasing relative teacher pay by $10 \%$ reduces arrest rates by $4-7 \%$. Unexpectedly, increasing pupil-teacher ratios (i.e. class size) by 1 student appears to reduce subsequent female arrest rates by 3-4\%. Columns 4-6 of Table 6 reveal that the effects of schooling policies are generally similar in sign across all three broad categories of crime - typically weakest for white collar crime and strongest for property crime.

\subsection{Educational Attainment}

While the main impacts of compulsory schooling laws on crime are likely to come through increased educational attainment, improvements in school quality may have both direct and indirect (i.e. through increases in completed schooling) effects as discussed in Section 2 . Returning to the Census data, we estimate the effects of both types of education policies on years of completed schooling for white women. Table 7 shows that stronger compulsory schooling laws and improvements in school quality lead to significantly higher levels of educational attainment. Based on column 3, increasing compulsory schooling ages to 11 years (from less than 9) increases completed schooling by nearly 0.1 years. A similar impact could be achieved by reducing pupil-teacher ratios by 3 students, increasing term length by 50 days, or increasing relative teacher wages by $25 \%$.

\subsection{Other Channels: Family, Work, and Earnings}

School policies and educational attainment likely impact female crime rates via several channels. Using Census data, Table 8 shows how minimum schooling attendance laws and school quality impact family structure for white women. Specifically, we estimate the extent to which these policies affect marriage rates, spousal education, and fertility behavior using the same covariates as in column 3 of Table 5. The first three columns report the effects of education policies on the probability of marriage. The next three columns report estimated effects on the probability a woman is married to someone with at least 12 years of schooling ${ }^{25}$ The probability of marriage and marriage to a high school graduate are both generally increasing in the minimum required years of schooling, pupil-teacher ratios, school term length, and teacher pay. (As with educational attainment, the effects of pupil-teacher ratios on marriage and spousal 'quality' are not what one might expect.) For the sample of all women (columns 1 and 4), a shift from 8 or less to 11 or more years of mandatory

\footnotetext{
${ }^{25}$ The dependent variable in these specifications is an indicator variable that is zero for women that are unmarried or married to high school dropouts.
} 
Table 6: Effects of Compulsory Schooling Laws and School Quality on Log Arrest Rates

\begin{tabular}{|c|c|c|c|c|c|c|}
\hline & \multicolumn{3}{|c|}{ All Offenses } & \multirow{2}{*}{$\begin{array}{c}\text { Property } \\
\text { (4) }\end{array}$} & \multirow{2}{*}{$\begin{array}{c}\text { Violent } \\
(5)\end{array}$} & \multirow{2}{*}{$\begin{array}{c}\text { White Collar } \\
(6)\end{array}$} \\
\hline & $(1)$ & $(2)$ & $(3)$ & & & \\
\hline \multirow[t]{2}{*}{ Compulsory attendance $=9$} & $-0.126^{* *}$ & $-0.116^{*}$ & -0.063 & $-0.274^{* *}$ & -0.134 & 0.087 \\
\hline & $(0.064)$ & $(0.065)$ & $(0.058)$ & $(0.099)$ & $(0.101)$ & $(0.080)$ \\
\hline \multirow[t]{2}{*}{ Compulsory attendance $=10$} & -0.102 & -0.096 & -0.080 & -0.185 & -0.146 & 0.052 \\
\hline & $(0.084)$ & $(0.085)$ & $(0.074)$ & $(0.117)$ & $(0.158)$ & $(0.109)$ \\
\hline \multirow{2}{*}{ Compulsory attendance $\geq 11$} & $-0.219^{* *}$ & $-0.187^{*}$ & -0.011 & $-0.327^{* *}$ & -0.210 & -0.003 \\
\hline & $(0.095)$ & $(0.098)$ & $(0.085)$ & $(0.161)$ & $(0.131)$ & $(0.092)$ \\
\hline \multirow[t]{2}{*}{ Pupil/Teacher ratio (10's of students) } & $-0.437^{* *}$ & $-0.388^{* *}$ & $-0.271^{* *}$ & $-0.558^{* *}$ & -0.253 & $-0.346^{* *}$ \\
\hline & $(0.112)$ & $(0.114)$ & $(0.135)$ & $(0.171)$ & $(0.182)$ & $(0.139)$ \\
\hline \multirow[t]{2}{*}{ Term length (100's of days) } & $-1.411^{* *}$ & $-1.345^{* *}$ & $-0.825^{* *}$ & $-1.541^{* *}$ & $-2.004^{* *}$ & -0.677 \\
\hline & $(0.330)$ & $(0.335)$ & $(0.351)$ & $(0.518)$ & $(0.500)$ & $(0.489)$ \\
\hline \multirow[t]{2}{*}{ Relative teacher wage } & $-0.666^{* *}$ & $-0.644^{* *}$ & $-0.360^{* *}$ & $-0.950^{* *}$ & $-0.558^{* *}$ & -0.269 \\
\hline & $(0.167)$ & $(0.175)$ & $(0.160)$ & $(0.203)$ & $(0.240)$ & $(0.234)$ \\
\hline F-statistic for CSL measures & 1.986 & 1.427 & 0.584 & 2.999 & 1.053 & 0.703 \\
\hline (p-value) & $(0.114)$ & $(0.233)$ & $(0.625)$ & $(0.030)$ & $(0.368)$ & $(0.550)$ \\
\hline F-statistic for school quality measures & 28.57 & 24.54 & 6.386 & 27.23 & 14.50 & 5.207 \\
\hline (p-value) & $(0.000)$ & $(0.000)$ & $(0.000)$ & $(0.000)$ & $(0.000)$ & $(0.001)$ \\
\hline \multicolumn{7}{|l|}{ Controls: } \\
\hline \multirow{7}{*}{$\begin{array}{l}\text { age } \times \text { offense effects } \\
\text { offense } \times \text { year effects } \\
\text { age } \times \text { year effects } \\
\text { state } \times \text { year } \\
\text { state } \times \text { offense effects } \\
\text { state } \times \text { offense } \times \text { year effects } \\
\text { state } \times \text { broad age group }\end{array}$} & $\mathrm{y}$ & $\mathrm{y}$ & $\mathrm{y}$ & $\mathrm{y}$ & $\mathrm{y}$ & $\mathrm{y}$ \\
\hline & $\mathrm{y}$ & $\mathrm{y}$ & $\mathrm{y}$ & $\mathrm{y}$ & $\mathrm{y}$ & $\mathrm{y}$ \\
\hline & $\mathrm{y}$ & $\mathrm{y}$ & $\mathrm{y}$ & $\mathrm{y}$ & $\mathrm{y}$ & $\mathrm{y}$ \\
\hline & $\mathrm{y}$ & $\mathrm{y}$ & $\mathrm{y}$ & $\mathrm{y}$ & $\mathrm{y}$ & $\mathrm{y}$ \\
\hline & $\mathrm{y}$ & $\mathrm{y}$ & $\mathrm{y}$ & $\mathrm{y}$ & $\mathrm{y}$ & $\mathrm{y}$ \\
\hline & & $\mathrm{y}$ & $\mathrm{y}$ & $\mathrm{y}$ & $\mathrm{y}$ & $\mathrm{y}$ \\
\hline & & & $\mathrm{y}$ & & & \\
\hline Number of Observations & 9,067 & 9,067 & 9,067 & 3,519 & 2,713 & 2,835 \\
\hline R-squared & 0.9420 & 0.9617 & 0.9639 & 0.9716 & 0.9336 & 0.9614 \\
\hline
\end{tabular}

Notes: The dependent variable is the logarithm of the arrest rate by age, type of offense, state, and year. Average schooling is by age group, state, and year. All models control for the percentage black. There are eight age groups: $20-24,25-29,30-34,35-39,40-44,45-49,50-54$, and 55-59. There are 50 states plus the District of Columbia and four years 1960, 1970, 1980, and 1990. All models are weighted by cell size calculated as the number of women in each cell from the Census. F-stastics are reported separately for tests of zero effects of all three compulsory attendance measures and for zero effects for all three school quality measures. Standard errors for state-year-age clustering are in parentheses. ${ }^{* *}$-value $<0.05$. ${ }^{*}$-value $<0.10$. 
Table 7: Effects of Compulsory Schooling Laws and School Quality on Educational Attainment for White Women

\begin{tabular}{|c|c|c|c|c|c|}
\hline & $(1)$ & $(2)$ & $(3)$ & $(4)$ & $(5)$ \\
\hline Compulsory attendance $=9$ & $\begin{array}{l}0.051^{* *} \\
(0.017)\end{array}$ & $\begin{array}{l}0.046^{* *} \\
(0.017)\end{array}$ & $\begin{array}{c}0.001 \\
(0.017)\end{array}$ & $\begin{array}{c}0.004 \\
(0.018)\end{array}$ & $\begin{array}{l}0.036^{* *} \\
(0.013)\end{array}$ \\
\hline Compulsory attendance $=10$ & $\begin{array}{l}0.143^{* *} \\
(0.024)\end{array}$ & $\begin{array}{l}0.133^{* *} \\
(0.023)\end{array}$ & $\begin{array}{l}0.070^{* *} \\
(0.022)\end{array}$ & $\begin{array}{l}0.085^{* *} \\
(0.022)\end{array}$ & $\begin{array}{l}0.062^{* *} \\
(0.018)\end{array}$ \\
\hline Compulsory attendance $\geq 11$ & $\begin{array}{l}0.191^{* *} \\
(0.023)\end{array}$ & $\begin{array}{l}0.186^{* *} \\
(0.022)\end{array}$ & $\begin{array}{l}0.092^{* *} \\
(0.021)\end{array}$ & $\begin{array}{l}0.108^{* *} \\
(0.023)\end{array}$ & $\begin{array}{l}0.100^{* *} \\
(0.018)\end{array}$ \\
\hline Pupil/Teacher ratio (10's of students) & $\begin{array}{c}-0.562^{* *} \\
(0.032)\end{array}$ & $\begin{array}{c}-0.511^{* *} \\
(0.032)\end{array}$ & $\begin{array}{c}-0.321^{* *} \\
(0.034)\end{array}$ & $\begin{array}{c}-0.389^{* *} \\
(0.034)\end{array}$ & $\begin{array}{c}-0.068^{* *} \\
(0.033)\end{array}$ \\
\hline Term length (100's of days) & $\begin{array}{c}0.071 \\
(0.106)\end{array}$ & $\begin{array}{l}0.231^{* *} \\
(0.104)\end{array}$ & $\begin{array}{c}0.194^{*} \\
(0.117)\end{array}$ & $\begin{array}{l}0.250^{* *} \\
(0.120)\end{array}$ & $\begin{array}{c}-0.399^{* *} \\
(0.102)\end{array}$ \\
\hline Relative teacher wage & $\begin{array}{l}0.317^{* *} \\
(0.049)\end{array}$ & $\begin{array}{l}0.313^{* *} \\
(0.048)\end{array}$ & $\begin{array}{l}0.377^{* *} \\
(0.055)\end{array}$ & $\begin{array}{l}0.372^{* *} \\
(0.056)\end{array}$ & $\begin{array}{l}0.202^{* *} \\
(0.041)\end{array}$ \\
\hline $\begin{array}{l}\text { F-statistic for CSL measures } \\
\text { (p-value) }\end{array}$ & $\begin{array}{c}27.19 \\
(0.000)\end{array}$ & $\begin{array}{c}28.64 \\
(0.000)\end{array}$ & $\begin{array}{l}10.10 \\
(0.000)\end{array}$ & $\begin{array}{c}12.34 \\
(0.000)\end{array}$ & $\begin{array}{l}11.29 \\
(0.000)\end{array}$ \\
\hline $\begin{array}{l}\text { F-statistic for school quality measures } \\
\text { (p-value) }\end{array}$ & $\begin{array}{c}177.5 \\
(0.000)\end{array}$ & $\begin{array}{c}163.2 \\
(0.000)\end{array}$ & $\begin{array}{c}63.21 \\
(0.000)\end{array}$ & $\begin{array}{c}86.14 \\
(0.000)\end{array}$ & $\begin{array}{l}11.08 \\
(0.000)\end{array}$ \\
\hline $\begin{array}{l}\text { Additional controls: } \\
\text { State of residence } \times \text { year effects } \\
\text { State of residence } \times \text { age } \\
\text { State of residence } \times \text { broad age group } \\
\text { Region of birth } \times \text { cohort trend }\end{array}$ & & $\mathrm{y}$ & $\begin{array}{l}\mathrm{y} \\
\mathrm{y}\end{array}$ & $\begin{array}{l}\mathrm{y} \\
\mathrm{y}\end{array}$ & $\mathrm{y}$ \\
\hline
\end{tabular}

Notes: The dependent variable is years of completed schooling. All regressions include dummies for state of residence, dummies for state of birth (excluding Alaska and Hawaii), dummies for age groups (age 20-22, 23-25, ... 56-58, and 59-60), dummies for decade of birth (1914-1923, 1924-1933, ..., 1964-1974), and dummies for census year. "broad age group" reflects three dummies for the following age groups: 20-34, 35-49, and 50-64. F-stastics are reported separately for tests of zero effects of all three compulsory attendance measures and for zero effects for all three school quality measures. The sample size is 3,495,789. Standard errors corrected for state of birth-year of birth clustering are in parentheses. ${ }^{* *}$ p-value $<0.05 .{ }^{*}$ p-value $<0.10$. 
schooling would raise marriage rates by 0.8 percentage points and marriage rates to high school graduates by 2.3 percentage points.

As discussed in Section 2, compulsory schooling laws may impact marital decisions by increasing a woman's own education or through changes in the education distribution and marital matching functions ${ }^{26}$ If marital matching is based primarily on educational attainment, then we can study the effects of schooling policies on marital matching functions by looking at the effects separately by female education. That is, if changes in schooling policy affect overall marriage rates or spousal education levels but have little impact on these outcomes conditional on female education, then the laws likely had little impact on marriage matching functions (i.e. how women and men are matched based on their educational attainment) ${ }^{27}$ However, if schooling policy has sizeable impacts on marriage rates and spousal education conditional on female education, then it is likely that marriage matching functions were impacted by the changing distributions of education among men and women.

Columns 2 and 3 of Table 8 show that marriage rates conditional on the woman's own education increased with compulsory schooling nearly as much as they did unconditionally, suggesting that marriage matching functions were affected. Columns 5 and 6 show that the probability of marrying more educated men also increased conditional on female schooling levels; however, these effects are much smaller than the unconditional results for all women. Moreover, much of this effect comes from the increases in marriage rates reported in columns 2 and 3 .

The presence of children in the household requires attention from mothers at home and likely raises the personal costs associated with incarceration. The existence of children may also alter women's social networks and build stronger family bonds. The last two columns of Table 8 report the effects of school policies on fertility behavior. These results suggest that schooling laws and improvements in all measures of school quality lead to significant increases in the number of own children in the household ${ }^{28}$ By contrast, there is little effect of the schooling laws or school quality measures on the likelihood of becoming a teen mother 29

Finally, we examine the effects of schooling policies on labor market outcomes and family earnings in Table 9 (using the same set of covariates). The first two columns suggest little systematic impact of these policies on female employment and work behavior. While 9 years of compulsory schooling seems to have modest positive effects on employment and weeks

\footnotetext{
${ }^{26}$ This is also true of school quality; however, we focus on the effects of compulsory schooling laws here, because we will use these laws as instruments for educational attainment below.

${ }^{27}$ In the model of Section 2 , this would mean that $\partial \theta / \partial L=0$.

${ }^{28}$ Here, our sample is restricted to women ages $20-40$ with the idea that most children should still be living at home.

${ }^{29}$ This specification restricts our sample to women ages 20-35 to ensure that children born when the mother was a teenager would still be in the household.
} 


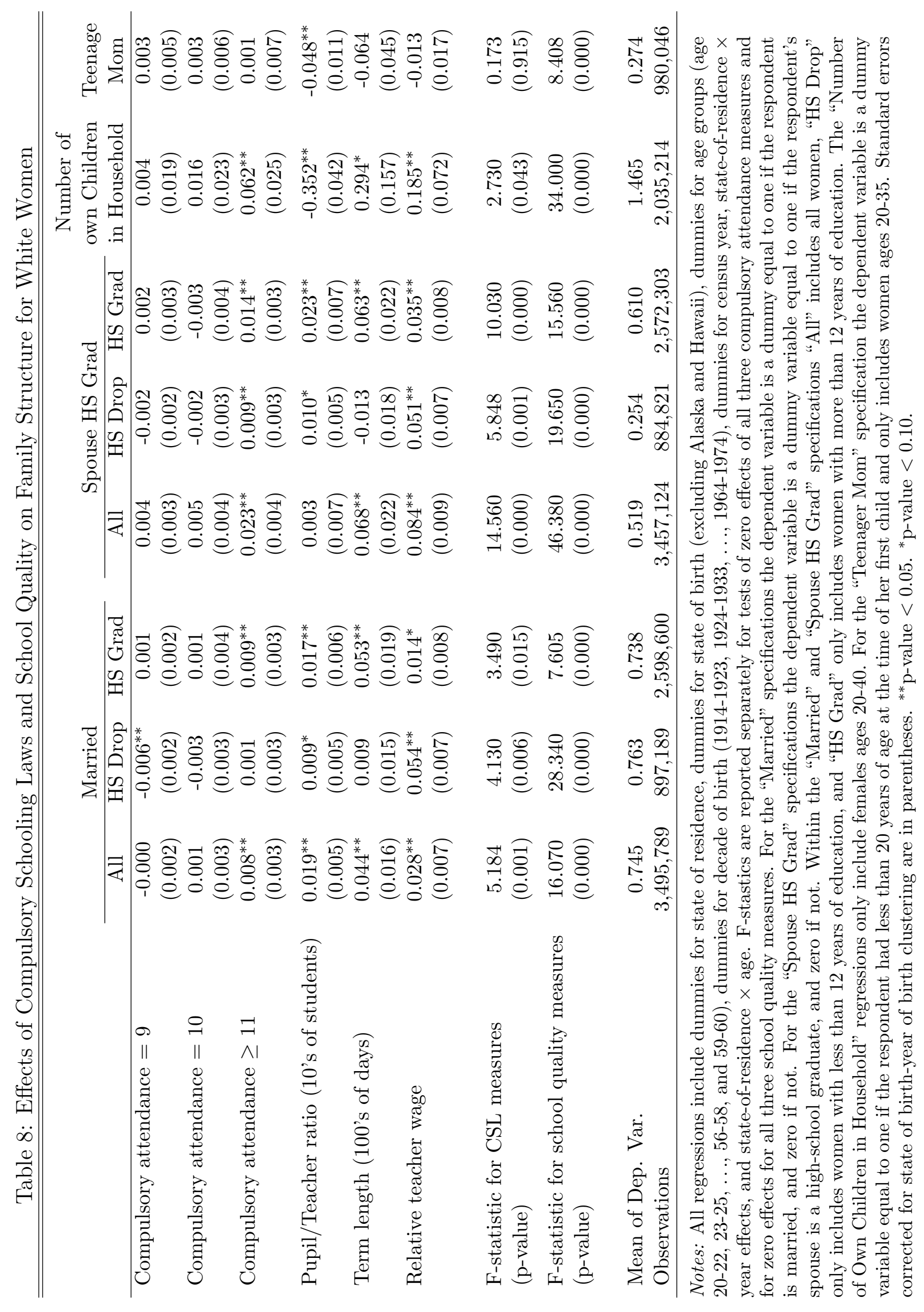


worked, higher compulsory schooling requirements do not. A 10 day longer school term leads to about .18 more weeks worked; however, a 10\% increase in relative teacher wages leads to a reduction of 0.08 weeks worked. As reported in column 3, the effects of education policies on female earnings are typically of the same sign as those on employment and weeks worked. Column 4 examines the impacts on spousal earnings, which are set to zero for unmarried women. Consistent with the effects of compulsory schooling laws on marriage, we observe a $\$ 568$ increase in spousal earnings associated with moving from less than 9 to 11 or more years of required schooling. A $20 \%$ increase in relative teacher wages raises spousal earnings by a similar amount, while changes in other quality measures have statistically and economically insignificant effects.

Altogether, these results suggest that raising compulsory schooling ages to 11 or more years would lead to moderate increases in marriage rates, spousal education and earnings, and

childbearing. Effects on a woman's own work and earnings, as well as teen motherhood, are small in magnitude and mostly statistically insignificant. Results are qualitatively similar when increasing the school year or teacher pay; although, extending the school year has more substantial effects on female earnings. Reductions in class size (as measured by pupilteacher ratios) also increase childbearing as well as teen motherhood; however, they appear to reduce marriage rates and spousal education, in contrast to improvements in the other quality measures.

\section{The Effect of Educational Attainment and School Quality on Female Crime}

In this section, we estimate the effects of educational attainment and school quality on incarceration and arrests using compulsory schooling laws as instruments for attainment. This analysis assumes that within-state changes in both compulsory schooling laws and school quality measures are exogenous. Given the impacts of the laws on marriage and concerns that marriage rates (and, to a lesser extent, spousal education) may have been affected by changes in the education distributions for men and women (altering marriage matching functions), we also use our Census data to explore specifications separately by marital status and that control for marital status along with schooling attainment and quality, instrumenting for both education and marriage. 
Table 9: Effects of Compulsory Schooling Laws and School Quality on Labor Supply and Earnings for White Women

\begin{tabular}{lcccc}
\hline \hline & & Weeks & & Spousal \\
& Employment & Worked & Earnings & Earnings \\
\hline Compulsory attendance $=9$ & $0.005^{* *}$ & $0.285^{* *}$ & $166.2^{* *}$ & -240.0 \\
& $(0.002)$ & $(0.097)$ & $(57.2)$ & $(162.7)$ \\
Compulsory attendance $=10$ & 0.002 & 0.146 & 32.4 & 32.0 \\
& $(0.003)$ & $(0.141)$ & $(87.7)$ & $(237.2)$ \\
Compulsory attendance $\geq 11$ & -0.003 & -0.092 & 6.4 & $567.8^{* *}$ \\
& $(0.002)$ & $(0.117)$ & $(73.5)$ & $(205.8)$ \\
Pupil/Teacher ratio (10's of students) & 0.007 & 0.318 & $449.3^{* *}$ & -280.1 \\
& $(0.005)$ & $(0.232)$ & $(146.1)$ & $(371.6)$ \\
Term length (100's of days) & 0.008 & $1.800^{* *}$ & $1,595.5^{* *}$ & 496.9 \\
& $(0.014)$ & $(0.712)$ & $(423.0)$ & $(1,103.1)$ \\
Relative teacher wage & $-0.017^{* *}$ & $-0.761^{* *}$ & $-446.3^{* *}$ & $2,785.1^{* *}$ \\
& $(0.007)$ & $(0.330)$ & $(208.1)$ & $(613.2)$ \\
F-statistic for CSL measures & & & & \\
(p-value) & 5.45 & 5.15 & 3.50 & 5.78 \\
F-statistic for school quality measures & $(0.00)$ & $(0.00)$ & $(0.02)$ & $(0.00)$ \\
(p-value) & 3.15 & 2.79 & 5.93 & 9.72 \\
Mean of Dep. Var. & 0.02 & 0.04 & 0.00 & 0.00 \\
Observations & & & & \\
\hline
\end{tabular}

Notes: All regressions include dummies for state of residence, dummies for state of birth (excluding Alaska and Hawaii), dummies for age groups (age 20-22, 23-25, .., 56-58, and 59-60), dummies for decade of birth (1914-1923, 1924-1933, ..., 1964-1974), dummies for census year, state-of-residence $\times$ year effects, and state-of-residence $\times$ age. F-stastics are reported separately for tests of zero effects of all three compulsory attendance measures and for zero effects for all three school quality measures. For "Employment" specifications, the dependent variable is a dummy equal to one if the respondent worked positive weeks last year, and zero if not. For the "Weeks Worked" specifications, the dependent variable is the number of weeks worked over the year, including respondents with zero weeks worked. For the "Earnings" and "Spousal Earnings" specifications, the dependent variable is the respondent's total pre-tax wage and salary income for the previous year expressed in 1999 US dollars. Standard errors corrected for state of birth-year of birth clustering are in parentheses. ${ }^{* *}$ p-value $<0.05 .{ }^{*}$ p-value $<0.10$. 


\subsection{Incarceration}

Using Census data, we now estimate the effects of educational attainment and school quality on the probability of incarceration:

$$
I_{i t}=s_{i t} \gamma_{s}+Q_{i t}^{\prime} \gamma_{Q}+X_{i t}^{\prime} \gamma_{X}+\epsilon_{i t}^{I}
$$

where $I_{i t}$ is an indicator variable equal to one if individual $i$ observed in year $t$ is incarcerated and zero otherwise; $s_{i t}$ reflects years of completed schooling for this individual; $Q_{i t}$ is the vector of school quality measures; and $X_{i t}$ is a vector of other observed covariates. (We control for the same sets of $X_{i t}$ covariates as when estimating equation (3) above.) As a reminder, controls for state-of-residence-specific time effects account for differences across states over time in terms of their law enforcement and criminal justice policies, as well as labor market conditions ${ }^{30}$ Controls for region-of-birth-specific cohort trends helps address concerns raised in Stephens and Yang (2014).

We begin by studying the effects of schooling attainment alone, omitting school quality measures. This serves two purposes. First, it allows us to see how adding controls for school quality measures affects estimated impacts of educational attainment on crime. Second, it allows us to estimate effects for black women as well as white women. Table 10 reports both ordinary least squares (OLS) and IV estimates of $\gamma_{s}$ (in percentage terms), the effect of one year of school on the probability of incarceration. Panel A reports estimates for white women and panel B for black women. OLS estimates indicate that an additional year of school, on average, lowers incarceration rates by about .006 percentage points for white women and .024 percentage points for black women. We account for the endogeneity of schooling by using compulsory attendance laws as instruments for educational attainment. The second line in both panels of Table 10 presents these IV estimates, which indicate that an additional year of school, on average, reduces incarceration rates by .04 to .06 percentage points among white women and .07 to .08 percentage points among black women ${ }^{31}$ While the estimated effects for whites are statistically significant (at 0.05 level), they are not for blacks due to the smaller sample sizes and resulting reduction in precision. The lack of precision for black women also means that we cannot reject equality of effects across races (based on the IV estimates). The estimates are quite robust across specifications and represent sizeable impacts relative

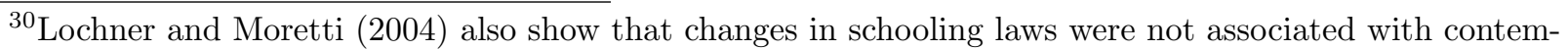
poraneous changes in enforcement expenditures or the number of police.

${ }^{31}$ First-stage estimates on the excluded instruments are statistically significant with F-statistics well above 10, the level below which concerns about weak instruments arise (Staiger and Stock, 1997). Consistent with Section 4.2 , the estimates indicate that increases in compulsory schooling ages lead to increases in educational attainment.
} 
Table 10: Effect of Years of Education on Imprisonment (in Percentage Terms)

\begin{tabular}{|c|c|c|c|c|c|}
\hline & $(1)$ & $(2)$ & $(3)$ & $(4)$ & $(5)$ \\
\hline \multicolumn{6}{|l|}{ A. White Females } \\
\hline OLS estimates & $\begin{array}{c}-0.006^{* *} \\
(0.000)\end{array}$ & $\begin{array}{c}-0.006^{* *} \\
(0.000)\end{array}$ & $\begin{array}{c}-0.006^{* *} \\
(0.000)\end{array}$ & $\begin{array}{c}-0.006^{* *} \\
(0.000)\end{array}$ & $\begin{array}{c}-0.006^{* *} \\
(0.000)\end{array}$ \\
\hline IV estimates & $\begin{array}{c}-0.035^{* *} \\
(0.010)\end{array}$ & $\begin{array}{c}-0.035^{* *} \\
(0.011)\end{array}$ & $\begin{array}{c}-0.052^{* *} \\
(0.021)\end{array}$ & $\begin{array}{c}-0.047^{* *} \\
(0.019)\end{array}$ & $\begin{array}{r}-0.059^{* *} \\
(0.028)\end{array}$ \\
\hline \multicolumn{6}{|l|}{ First-Stage: } \\
\hline Compulsory attendance $=9$ & $\begin{array}{l}0.146^{* *} \\
(0.019)\end{array}$ & $\begin{array}{l}0.137^{* *} \\
(0.019)\end{array}$ & $\begin{array}{l}0.064^{* *} \\
(0.017)\end{array}$ & $\begin{array}{l}0.071^{* *} \\
(0.018)\end{array}$ & $\begin{array}{l}0.049^{* *} \\
(0.014)\end{array}$ \\
\hline Compulsory attendance $=10$ & $\begin{array}{l}0.220^{* *} \\
(0.027)\end{array}$ & $\begin{array}{l}0.202^{* *} \\
(0.026)\end{array}$ & $\begin{array}{l}0.118^{* *} \\
(0.024)\end{array}$ & $\begin{array}{l}0.136^{* *} \\
(0.024)\end{array}$ & $\begin{array}{l}0.074^{* *} \\
(0.020)\end{array}$ \\
\hline Compulsory attendance $\geq 11$ & $\begin{array}{l}0.324^{* *} \\
(0.025)\end{array}$ & $\begin{array}{l}0.309^{* *} \\
(0.024)\end{array}$ & $\begin{array}{l}0.178^{* *} \\
(0.022)\end{array}$ & $\begin{array}{l}0.200^{* *} \\
(0.024)\end{array}$ & $\begin{array}{l}0.129^{* *} \\
(0.019)\end{array}$ \\
\hline F-statistic for excluded instruments & 55.49 & 53.83 & 22.75 & 24.86 & 15.03 \\
\hline \multicolumn{6}{|l|}{ B. Black Females } \\
\hline OLS estimates & $\begin{array}{c}-0.024^{* *} \\
(0.002)\end{array}$ & $\begin{array}{c}-0.024^{* *} \\
(0.002)\end{array}$ & $\begin{array}{c}-0.024^{* *} \\
(0.002)\end{array}$ & $\begin{array}{c}-0.024^{* *} \\
(0.002)\end{array}$ & $\begin{array}{c}-0.024^{* *} \\
(0.002)\end{array}$ \\
\hline IV estimates & $\begin{array}{c}-0.078^{*} \\
(0.044)\end{array}$ & $\begin{array}{l}-0.077 \\
(0.047)\end{array}$ & $\begin{array}{l}-0.066 \\
(0.080)\end{array}$ & $\begin{array}{l}-0.080 \\
(0.071)\end{array}$ & $\begin{array}{l}-0.083 \\
(0.106)\end{array}$ \\
\hline \multicolumn{6}{|l|}{ First-Stage: } \\
\hline Compulsory attendance $=9$ & $\begin{array}{l}0.384^{* *} \\
(0.037)\end{array}$ & $\begin{array}{c}0.358^{* *} \\
(0.036)\end{array}$ & $\begin{array}{l}0.225^{* *} \\
(0.030)\end{array}$ & $\begin{array}{l}0.252^{* *} \\
(0.031)\end{array}$ & $\begin{array}{l}0.174^{* *} \\
(0.030)\end{array}$ \\
\hline Compulsory attendance $=10$ & $\begin{array}{l}0.431^{* *} \\
(0.063)\end{array}$ & $\begin{array}{l}0.393^{* *} \\
(0.062)\end{array}$ & $\begin{array}{l}0.241^{* *} \\
(0.054)\end{array}$ & $\begin{array}{l}0.282^{* *} \\
(0.056)\end{array}$ & $\begin{array}{l}0.190^{* *} \\
(0.048)\end{array}$ \\
\hline Compulsory attendance $\geq 11$ & $\begin{array}{l}0.452^{* *} \\
(0.056)\end{array}$ & $\begin{array}{l}0.428^{* *} \\
(0.055)\end{array}$ & $\begin{array}{l}0.264^{* *} \\
(0.044)\end{array}$ & $\begin{array}{l}0.314^{* *} \\
(0.046)\end{array}$ & $\begin{array}{l}0.203^{* *} \\
(0.044)\end{array}$ \\
\hline F-statistic for excluded instruments & 39.22 & 35.88 & 19.68 & 24.33 & 11.82 \\
\hline \multicolumn{6}{|l|}{ Additional controls: } \\
\hline State of residence $\times$ year effects & & $\mathrm{y}$ & $\mathrm{y}$ & $\mathrm{y}$ & $\mathrm{y}$ \\
\hline State of residence $\times$ age & & & $\mathrm{y}$ & & \\
\hline $\begin{array}{l}\text { State of residence } \times \text { broad age group } \\
\text { Region of birth } \times \text { cohort trend }\end{array}$ & & & & $\mathrm{y}$ & $\mathrm{y}$ \\
\hline
\end{tabular}

Notes: All regressions include dummies for state of residence, dummies for state of birth (excluding Alaska and Hawaii), dummies for age groups (age 20-22, 23-25, .., 56-58, and 59-60), dummies for decade of birth (1914-1923, 1924-1933, ..., 1964-1974), and dummies for census year. The regressions for black females also include state-of-birth dummies interacted with a dummy for black women born in the South who turn age 14 in 1958 or later to account for the impact of Brown v. Board of Education. "broad age group" reflects three dummies for the following age groups: 20-34, 35-49, and 50-64. The F-test for excluded instruments for white females is distributed $F_{(3,2985)}$ and for black females is distributed $F_{(3,2568)}$. The sample size for white females is $3,613,313$ and for black females is 480,709 . Standard errors corrected for state of birth-year of birth clustering are in parentheses. ${ }^{* *}$ p-value $<0.05 .{ }^{*}$ p-value $<0.10$. 
to baseline incarceration rates for uneducated women.

The fact that IV estimates are significantly larger (in absolute value) than OLS estimates for white women is consistent with the findings of Lochner and Moretti (2004) and Machin et al. (2011) for men. This may suggest that unmeasured factors which lead to higher levels of schooling also lead to higher rates of incarceration, contrary to most theories of crime. More likely, the larger IV estimates are due to heterogeneity in the impacts of additional schooling across individuals and across grade margins. With both types of heterogeneity, IV estimates will reflect average impacts of an additional year of school for those women (and grades) that are impacted by the changing schooling laws, while OLS estimates reflect average effects in the population (along with any endogeneity bias). For example, IV estimates would be greater than OLS estimates (in the absence of endogeneity) if the effects of schooling on crime are greatest among young women that are most responsive to compulsory schooling laws ${ }^{32}$ It may also be the case that additional schooling at the grade margins affected by the instrument (i.e. grades 9-12) has particularly strong effects on incarceration, as suggested by Figure 1. This, too, can lead to larger IV estimates (Lochner and Moretti, 2015).33

As discussed in Stephens and Yang (2014), failure to account for changes in school quality, which are correlated with changes in compulsory schooling ages (see Table 4), may lead to standard omitted variable bias (for both OLS and IV estimates). We next incorporate our three measures of quality, focusing on white women for reasons discussed earlier. Table 11 reports IV estimates of the effects of educational attainment along with estimated effects of school quality. The estimated impacts of educational attainment are slightly greater in magnitude than those in Table 10, Even though the first-stage effects of schooling laws are weaker than when we omit quality measures, they are still significant (with F-statistics exceeding 10) and suggest that tougher compulsory schooling laws are associated with more years of education 34

Table 11 suggests little direct effect of school quality on the likelihood of incarceration. Only coefficients on relative teacher wages are statistically significant across most specifications; however, they suggest that higher teacher wages increase the probability of incarcera-

\footnotetext{
${ }^{32}$ See Imbens and Angrist (1994) for a discussion of local average treatment effects and instrumental variables.

${ }^{33}$ Applying the exogeneity test of Lochner and Moretti (2015), which is robust to heterogeneous gradespecific effects, we reject exogeneity of schooling for whites but not blacks (e.g. p-values of 0.041 and 0.564, respectively, for specification 3 in Table 10 . This suggests that the difference between OLS and IV estimates for white women is not fully explained by greater impacts of education at some grade margins than others.

${ }^{34}$ These results alleviate concerns raised by Stephens and Yang (2014) regarding the ability to instrument for schooling using compulsory schooling laws due to contemporaneous changes in school quality - for white women, at least. The first-stage effects of compulsory schooling laws on completed schooling are much weaker for white men with F-statistics of around 10 for specifications reported in columns 1 and 2 of Table 11 and much lower for specifications reported in columns 3-5 of the table.
} 
Table 11: IV Estimates of the Effects of Education and School Quality on Imprisonment for White Women (in Percentage Terms)

\begin{tabular}{lccccc}
\hline \hline & $(1)$ & $(2)$ & $(3)$ & $(4)$ & $(5)$ \\
\hline Years of education & $-0.061^{* *}$ & $-0.058^{* *}$ & $-0.094^{* *}$ & $-0.078^{* *}$ & $-0.066^{*}$ \\
& $(0.018)$ & $(0.018)$ & $(0.037)$ & $(0.031)$ & $(0.038)$ \\
Pupil/Teacher ratio (10's of students) & $-0.027^{* *}$ & -0.020 & -0.021 & -0.021 & 0.001 \\
& $(0.013)$ & $(0.013)$ & $(0.015)$ & $(0.015)$ & $(0.008)$ \\
Term length (100's of days) & -0.008 & 0.005 & -0.004 & -0.006 & $-0.050^{*}$ \\
& $(0.020)$ & $(0.021)$ & $(0.027)$ & $(0.026)$ & $(0.028)$ \\
Relative teacher wage & $0.029^{* *}$ & $0.026^{* *}$ & $0.043^{* *}$ & $0.038^{* *}$ & 0.017 \\
& $(0.010)$ & $(0.010)$ & $(0.018)$ & $(0.016)$ & $(0.013)$ \\
First Stage & & & & & \\
Compulsory attendance $=9$ & $0.051^{* *}$ & $0.046^{* *}$ & 0.001 & 0.004 & $0.036^{* *}$ \\
& $(0.017)$ & $(0.017)$ & $(0.017)$ & $(0.018)$ & $(0.013)$ \\
Compulsory attendance $=10$ & $0.143^{* *}$ & $0.133^{* *}$ & $0.070^{* *}$ & $0.085^{* *}$ & $0.062^{* *}$ \\
& $(0.024)$ & $(0.023)$ & $(0.022)$ & $(0.022)$ & $(0.018)$ \\
Compulsory attendance $\geq 11$ & $0.191^{* *}$ & $0.186^{* *}$ & $0.092^{* *}$ & $0.108^{* *}$ & $0.100^{* *}$ \\
& $(0.023)$ & $(0.022)$ & $(0.021)$ & $(0.023)$ & $(0.018)$ \\
F-statistic for excluded instruments & 27.19 & 28.64 & 10.1 & 12.34 & 11.29 \\
& & & & & \\
Additional controls: & & & & & $\mathrm{y}$ \\
State of residence $\times$ year effects & & $\mathrm{y}$ & $\mathrm{y}$ & $\mathrm{y}$ & $\mathrm{y}$ \\
State of residence $\times$ age & & & & & $\mathrm{y}$ \\
State of residence $\times$ broad age group & & & & & $\mathrm{y}$ \\
Region of birth $\times$ cohort trend & & & & & \\
\hline
\end{tabular}

Notes: All regressions include dummies for state of residence, dummies for state of birth (excluding Alaska and Hawaii), dummies for age groups (age 20-22, 23-25, ..., 56-58, and 59-60), dummies for decade of birth (1914-1923, 1924-1933, ..., 1964-1974), and dummies for census year. "broad age group" reflects three dummies for the following age groups: $20-34,35-49$, and 50-64. The F-test for excluded instruments is distributed $F_{(3,2692)}$. The sample size is $3,495,789$. Standard errors corrected for state of birth-year of birth clustering are in parentheses. ${ }^{* *}$ p-value $<0.05$. ${ }^{*}$ p-value $<0.10$.

tion (holding schooling constant) ${ }^{35}$ One concern is that there may be too little independent variation in our three measures of school quality to obtain precise estimates of each measure's effect. We show in Appendix D (online) that including each quality measure by itself produces very similar results to those in Table 11. Furthermore, including a single factor extracted from all three quality measures yields negligible effects of this 'quality factor'.

Table 7 shows that improvements in all three quality measures (i.e. lower pupil-teacher ratios, longer school terms, and higher teacher wages) lead to significantly higher levels of educational attainment among white women ${ }^{36}$ Thus, school quality improvements indirectly

\footnotetext{
${ }^{35}$ Adding interactions for region of residence $\times$ region of birth to specification 2 as suggested in Heckman et al. (1996) produces very similar results. Results available upon request.

${ }^{36}$ The estimated effect of term length in column 1 is the sole exception.
} 
reduce incarceration rates by increasing schooling attainment. In most specifications, these indirect effects are stronger than the direct effects for pupil-teacher ratios and term length, while they are very similar in magnitude (and of opposite sign) for teacher wages. Based on the estimates reported in columns 3 or 4 of Tables 7 and 11, the total effect of a 1 student reduction per teacher or a $10 \%$ increase in relative teacher pay would be to lower the probability of incarceration by .001 percentage points, while an extra 10 days added to the school year would result in a reduction of slightly more than twice that size ${ }^{37}$

The greatest concern with our IV estimation strategy is the potential effects of schooling laws on marriage matching functions. We address this issue in Table 12 , focusing on specifications that omit the school quality measures (analogous to column 3 in Table 10), since our attention is on the impacts of schooling attainment (and its estimated effect is not very sensitive to controls for school quality) ${ }^{38}$ The first two columns report the effects of schooling obtained from estimating the model separately by marital status. The estimated effects are both negative, with larger (and statistically significant) effects for single women.

The next two columns of Table 12 also estimate our model separately by marital status but use a control function approach to account for endogenous selection. This approach relies on exogenous variation in the probability of marriage, which we estimate as a function of our exogenous $X_{i t}$ regressors, schooling laws $L_{i t}$, and two additional sets of variables: quarter of birth indicators and compulsory schooling ages when women were age 10 . The first of these additional variable sets is assumed to affect both marriage and educational attainment, while the second is assumed to affect marriage only ${ }^{39}$ Marriage laws when women were age 10 should not affect their schooling conditional on the laws when they were age $14, L_{i t}$; however, they are likely to affect potential spousal education and marriage decisions, since most women marry men that are a few years older. The estimates correcting for selection into marriage are similar to those that do not (compare the first two with the second two columns in Table 12). An extra year of schooling reduces the probability of incarceration by about .026 percentage points for married women and 0.043 percentage points for single

\footnotetext{
${ }^{37}$ Total effects are calculated by summing the direct and indirect effects, where the latter are obtained by taking the estimated effects of schooling attainment on incarceration from Table 11 and multiplying them by the estimated effects of quality on years of schooling reported in Table 7.

${ }^{38}$ Estimated effects of schooling attainment are slightly larger when we control for school quality measures. See Table D-3 in Appendix D (online).

${ }^{39}$ Our control function approach assumes that marriage is based on a single index model with:
}

$$
m_{i t}^{*}=X_{i t}^{\prime} \mu_{X}+Z_{i t}^{\prime} \mu_{Z}-\xi_{i t}
$$

where marriage is given by the indicator $m_{i t}=1\left(m_{i t}^{*}>0\right), \xi_{i t} \Perp\left(X_{i t}, Z_{i t}\right)$, and $Z_{i t}$ are exogenous instruments affecting marriage,. In practice, we first estimate the probability of marriage conditional on $(X, Z)$, $\hat{P}_{i}(X, Z)$, assuming $\xi_{i t} \sim N\left(0, \sigma_{\xi}^{2}\right)$. We then include $\hat{P}_{i}$ and $\hat{P}_{i}^{2}$ in our incarceration estimating equation as additional regressors and perform two-stage least squares. See Appendix C for details. 
women, where the former is statistically significant and the latter is not. The point estimates are quite similar, and one cannot reject that they are the same given their standard errors.

Finally, we simultaneously control for both marriage and educational attainment (for the full sample of women) in the final two columns of Table 12. Here, we treat both schooling and marriage as endogenous, using our compulsory schooling laws and quarter of birth indicators as instruments. The table reports first stage estimates for both endogenous variables, along with F-statistics for the excluded instruments. The instruments are reasonably strong for both endogenous variables; however, we only obtain precise estimates of the effect of schooling. The estimated effect of an extra year of school is -.035 percentage points, roughly half-way between the selection corrected estimates for married and single women. This estimate is about $30 \%$ smaller than the corresponding estimate in column 3 of Table 10 for two reasons. First, by controlling for marital status, the estimated effect of education in Table 12 does not incorporate any effects of education on crime resulting from changes in marital status. Second, the IV estimate in Table 10 may be biased towards finding too large an effect if changes in schooling laws altered marriage matching functions so women were more likely to marry regardless of their schooling (as suggested by Table 8). The similarity in estimates whether we control for marital status or not suggests that any bias from this is unlikely to be very large.

\subsection{Arrest Rates}

Next, we use our merged UCR and Census data to study the impacts of educational attainment and school quality on female arrest rates for property, violent, and white collar offenses. The basic relationship we estimate is:

$$
\ln \left(A_{\text {calt }}\right)=s_{\text {alt }} \delta_{s}+Q_{\text {alt }}^{\prime} \delta_{Q}+X_{\text {calt }}^{\prime} \delta_{X}+\epsilon_{\text {calt }}^{A}
$$

where $\ln \left(A_{\text {calt }}\right)$ is the natural logarithm of the female arrest rate as defined earlier; $s_{\text {alt }}$ and $Q_{\text {alt }}$ are average years of schooling and school quality for women in age group $a$ living in state $l$ in year $t$; and $X_{\text {calt }}$ is the same vector of covariates used in estimating equation (4) above. These covariates include the proportion of black females in age group $a$ in state $l$ in year $t$ as well as indicator variables to control for unobserved heterogeneity across states, age groups, criminal offenses, and years. Most notably, the many fixed effects effectively account for variation in enforcement policies and labor markets across states and over time (by offense type), differences in age profiles by offense type, and systematic variation in age-crime profiles over time and across states.

Recall that because our arrest measures (by offense) are only available as aggregates at 


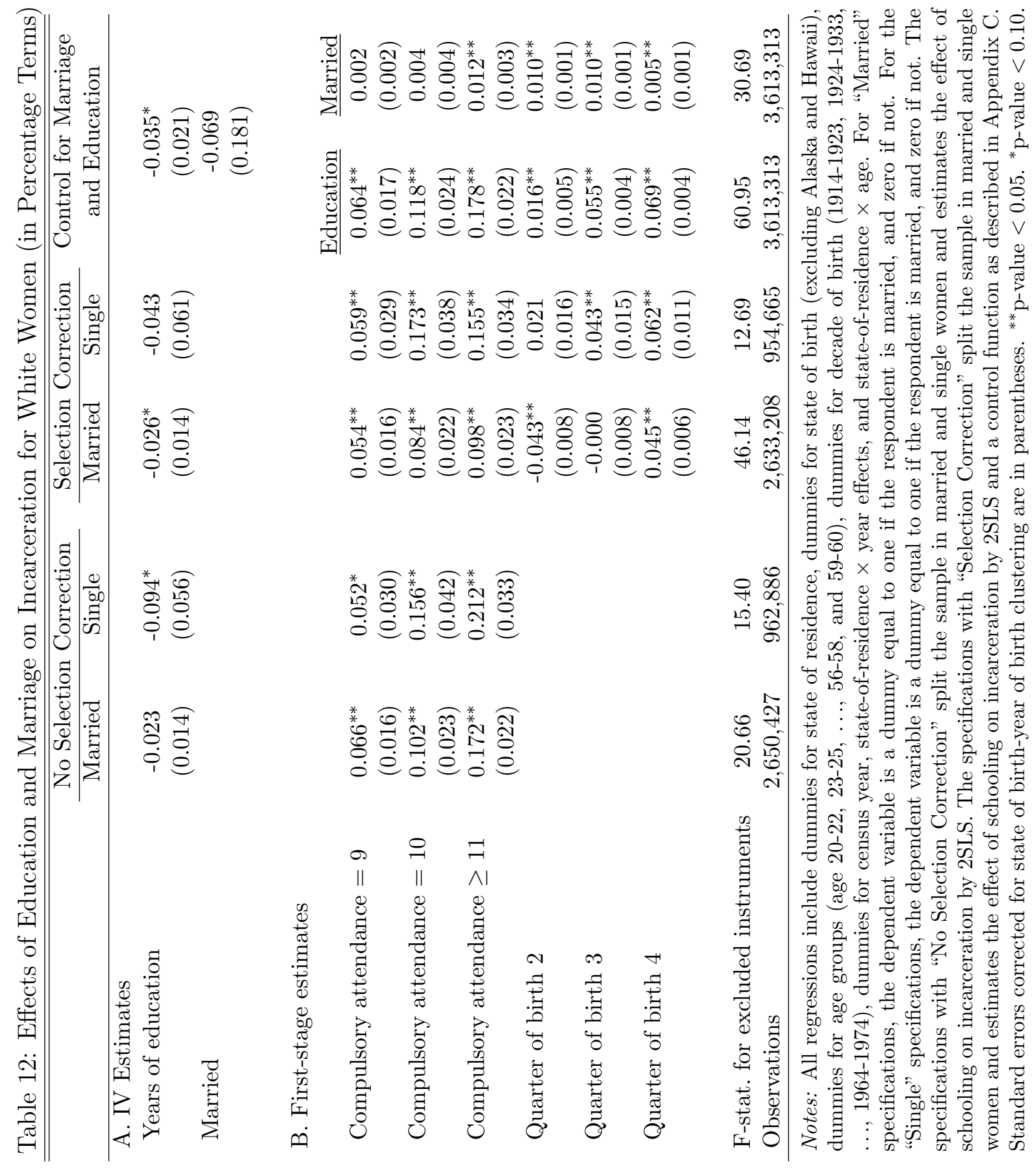


the age, state, and year level, we cannot distinguish between state of birth and state of residence. By construction, our instruments and quality measures only vary at the statecohort level, so it is not possible to control for unrestricted state-age and state-year effects due to multicollinearity. To flexibly account for different enforcement policies across states over time, we control for state-year effects. We also explore including controls for broad age group (i.e. ages 20-34, 35-49, 50-60) effects by state; however this proves too demanding in most cases.

We begin by considering specifications that do not control for school quality measures, reporting these results in Table 13 . The first three columns of the table present OLS estimates of the effects of education on log arrest rates for all crimes (panel A) and separately for violent, property, and white collar offenses (panel B) 40 The estimates in panel A indicate that a one-year increase in average years of schooling among women is associated with a 1215 percent decline in female arrest rates. Panel B shows that a one-year increase in average education reduces arrest rates by about 30 percent for violent crimes (murder, robbery, assault) and roughly 10 percent for property crimes (burglary, larceny, motor vehicle theft, arson). Estimated effects of education on arrests for white collar offenses (forgery, fraud, embezzlement) are negligible and statistically insignificant. Table D-5 in Appendix D (online) examines arrests by more detailed offense types, estimating separate models (using OLS) for violent offenses, property offenses, and white collar offenses. These estimates reveal strong effects of education on murder, assault, motor vehicle theft, and embezzlement, all decreasing more than 30 percent in response to a one year increase in average schooling levels. It is also noteworthy that education appears to increase forgery, with estimates statistically significant in the first two specifications.

Columns 4-6 of Table 13 report estimates using the changes in compulsory schooling laws as instruments for educational attainment. The weaker first-stage effects of compulsory attendance laws on average education (compared to the effects reported in Table 10 for our individual-level analysis of incarceration) are not surprising, since our aggregated data do not allow us to exploit variation in the laws across states of birth within current state of residence. Still, in columns 4 and 5, which do not include state-specific age-group fixed effects, the first-stage F-statistics for the excluded instruments satisfy conventional criteria for "strong" instruments (Staiger and Stock, 1997) and yield IV estimates that are precise enough to rule out small effects for all but white collar crime. For example, column 5 suggests that a one-year increase in average years of schooling reduces arrests for violent crime by about 50 percent and property crime by 67 percent, both statistically significant. Controlling for state-

\footnotetext{
${ }^{40}$ Estimates using the high school completion rates rather than years of education as the main variable of interest yield qualitatively similar results and are available upon request.
} 
Table 13: Effects of Average Schooling on Log Arrest Rates

\begin{tabular}{|c|c|c|c|c|c|c|}
\hline & \multicolumn{3}{|c|}{ OLS Estimates } & \multicolumn{3}{|c|}{ IV Estimates } \\
\hline & $(1)$ & $(2)$ & $(3)$ & $(4)$ & $(5)$ & $(6)$ \\
\hline A. All Offenses & $\begin{array}{c}-0.146^{* *} \\
(0.056)\end{array}$ & $\begin{array}{c}-0.128^{* *} \\
(0.056)\end{array}$ & $\begin{array}{c}-0.117^{* *} \\
(0.056)\end{array}$ & $\begin{array}{c}-0.401^{* *} \\
0.115)\end{array}$ & $\begin{array}{c}-0.367^{* *} \\
(0.111)\end{array}$ & $\begin{array}{c}-0.491^{* *} \\
(0.247)\end{array}$ \\
\hline \multicolumn{7}{|l|}{ First Stage } \\
\hline Compulsory attendance $=9$ & & & & $\begin{array}{l}0.389^{* *} \\
(0.056)\end{array}$ & $\begin{array}{l}0.391^{* *} \\
(0.060)\end{array}$ & $\begin{array}{l}0.179^{* *} \\
(0.044)\end{array}$ \\
\hline Compulsory attendance $=10$ & & & & $\begin{array}{l}0.490^{* *} \\
(0.066)\end{array}$ & $\begin{array}{l}0.492^{* *} \\
(0.070)\end{array}$ & $\begin{array}{l}0.245^{* *} \\
(0.052)\end{array}$ \\
\hline Compulsory attendance $\geq 11$ & & & & $\begin{array}{l}0.582^{* *} \\
(0.076)\end{array}$ & $\begin{array}{l}0.584^{* *} \\
(0.081)\end{array}$ & $\begin{array}{l}0.224^{* *} \\
(0.061)\end{array}$ \\
\hline F-statistic for excluded instruments & & & & 21.88 & 19.34 & 7.53 \\
\hline \multicolumn{7}{|l|}{ B. Effects by Broad Offense Type } \\
\hline Violent crime & $\begin{array}{c}-0.362^{* *} \\
(0.060)\end{array}$ & $\begin{array}{c}-0.306^{* *} \\
(0.063)\end{array}$ & $\begin{array}{c}-0.291^{* *} \\
(0.062)\end{array}$ & $\begin{array}{c}-0.700^{* *} \\
(0.128)\end{array}$ & $\begin{array}{c}-0.502^{* *} \\
(0.145)\end{array}$ & $\begin{array}{l}-0.648^{*} \\
(0.252)\end{array}$ \\
\hline Property crime & $\begin{array}{c}-0.139^{* *} \\
(0.062)\end{array}$ & $\begin{array}{l}-0.091 \\
(0.065)\end{array}$ & $\begin{array}{l}-0.082 \\
(0.063)\end{array}$ & $\begin{array}{c}-0.647^{* *} \\
(0.173)\end{array}$ & $\begin{array}{c}-0.669^{* *} \\
(0.186)\end{array}$ & $\begin{array}{r}-0.801^{* *} \\
(0.287)\end{array}$ \\
\hline White collar crime & $\begin{array}{c}0.059 \\
(0.062)\end{array}$ & $\begin{array}{c}0.002 \\
(0.058)\end{array}$ & $\begin{array}{c}0.019 \\
(0.063)\end{array}$ & $\begin{array}{c}0.178 \\
(0.137)\end{array}$ & $\begin{array}{c}0.128 \\
(0.134)\end{array}$ & $\begin{array}{c}0.009 \\
(0.261)\end{array}$ \\
\hline \multicolumn{7}{|l|}{ Controls: } \\
\hline age $\times$ offense effects & $\mathrm{y}$ & $\mathrm{y}$ & $\mathrm{y}$ & $\mathrm{y}$ & $\mathrm{y}$ & $\mathrm{y}$ \\
\hline offense $\times$ year effects & $\mathrm{y}$ & $\mathrm{y}$ & $\mathrm{y}$ & $\mathrm{y}$ & $\mathrm{y}$ & $\mathrm{y}$ \\
\hline age $\times$ year effects & $\mathrm{y}$ & $\mathrm{y}$ & $\mathrm{y}$ & $\mathrm{y}$ & $\mathrm{y}$ & $\mathrm{y}$ \\
\hline state $\times$ year & $\mathrm{y}$ & $\mathrm{y}$ & $\mathrm{y}$ & $\mathrm{y}$ & $\mathrm{y}$ & $\mathrm{y}$ \\
\hline state $\times$ offense effects & $\mathrm{y}$ & $\mathrm{y}$ & $\mathrm{y}$ & $\mathrm{y}$ & $\mathrm{y}$ & $\mathrm{y}$ \\
\hline $\begin{array}{l}\text { state } \times \text { offense } \times \text { year effects } \\
\text { state } \times \text { broad age group }\end{array}$ & & $\mathrm{y}$ & $\mathrm{y}$ & & $\mathrm{y}$ & $\mathrm{y}$ \\
\hline
\end{tabular}

Notes: The dependent variable is the logarithm of the arrest rate by age, type of offense, state, and year. Average schooling is by age group, state, and year. All models control for the percentage black. There are eight age groups: $20-24,25-29,30-34,35-39,40-44,45-49,50-54$, and 55-59. There are 50 states plus the District of Columbia and four years 1960, 1970, 1980, and 1990. All models are weighted by cell size calculated as the number of women in each cell from the Census. The F-test for excluded instruments is distributed $F_{(3,1403)}$. Standard errors for state-year-age clustering are in parentheses. ${ }^{* *}$ p-value $<0.05 .{ }^{*}$ p-value $<0.10$. 
specific age group effects (column 6) produces much less precise estimates. Simultaneously controlling for state-specific year effects and state-specific age effects leaves little available within-state variation across cohorts even when the state-age effects are based on broad age groups of $10-15$ years.

We now include our three measures of state- and cohort-specific school quality in estimating equation (6). 41 Table 14 reports OLS and IV estimates, where we estimate the effects of average education on all types of offenses. Except for columns 3 and 6, which include state-specific age effects, both OLS and IV estimates of the impact of average educational attainment are statistically significant and very similar to their counterparts that do not control for school quality (Table 13) ${ }^{42}$

The effects of school quality on arrest rates are also statistically significant for all three measures of quality; however, the estimated effects of pupil/teacher ratios is the opposite of what one might expect. This should not be surprising given our findings in Table6. Holding average years of schooling constant, increases in the pupil/teacher ratio, term length, and teacher salary all lead to subsequent reductions in female arrest rates. Columns 4 and 5 indicate that a one student increase per teacher reduces female arrest rates by 8-9 percent, a 10 day increase in term length reduces female arrest rates by about 12 percent, and a 10 percent increase in teacher wages above the national average reduces female arrest rates by about 5 percent 43

Online Appendix Table D-6 reports separate IV estimates for each broad type of offense. The results show that increases in average education significantly reduce female arrest rates for violent and property offenses but have no significant effect on arrests for white-collar offenses. Increases in term length significantly reduce violent crime arrests, increases in teacher wages significantly reduce property crime arrests, and increases in the pupil/teacher ratio significantly reduce arrests for all types of crime.

\section{Why does Education Reduce Female Crime?}

As discussed in Section 2, education and school quality impact many aspects of life which may lead to reductions in crime. By raising skill levels, they can improve labor market opportunities. They may also impact family structure via marriage opportunities and child-

\footnotetext{
${ }^{41}$ See Appendix $\mathrm{A}$ for details on our treatment of these data.

${ }^{42}$ Once we control for state-specific age effects (columns 3 and 6 ), compulsory schooling laws become weak instruments as evidenced by the low F-statistic.

${ }^{43}$ The indirect effects of improvements in quality through increased schooling attainment are all positive but smaller (in absolute value) than the direct effects. Therefore, the total effect of the pupil-teacher ratio is still of unexpected sign.
} 
Table 14: Effects of Education and School Quality on Log Arrest Rates

\begin{tabular}{|c|c|c|c|c|c|c|}
\hline & \multicolumn{3}{|c|}{ OLS Estimates } & \multicolumn{3}{|c|}{ IV Estimates } \\
\hline & $(1)$ & $(2)$ & $(3)$ & $(4)$ & $(5)$ & $(6)$ \\
\hline Years of education & $\begin{array}{c}-0.180^{* *} \\
(0.070)\end{array}$ & $\begin{array}{c}-0.147^{* *} \\
(0.071)\end{array}$ & $\begin{array}{l}-0.065 \\
(0.065)\end{array}$ & $\begin{array}{c}-0.510^{* *} \\
(0.226)\end{array}$ & $\begin{array}{c}-0.442^{* *} \\
(0.218)\end{array}$ & $\begin{array}{l}-0.330 \\
(0.405)\end{array}$ \\
\hline Pupil/Teacher ratio (10's of students) & $\begin{array}{c}-0.510^{* *} \\
(0.118)\end{array}$ & $\begin{array}{c}-0.440^{* *} \\
(0.122)\end{array}$ & $\begin{array}{c}-0.302^{* *} \\
(0.143)\end{array}$ & $\begin{array}{c}-0.892^{* *} \\
(0.257)\end{array}$ & $\begin{array}{c}-0.784^{* *} \\
(0.249)\end{array}$ & $\begin{array}{l}-0.468 \\
(0.288)\end{array}$ \\
\hline Term length (100's of days) & $\begin{array}{c}-1.330^{* *} \\
(0.327)\end{array}$ & $\begin{array}{c}-1.286^{* *} \\
(0.333)\end{array}$ & $\begin{array}{c}-0.885^{* *} \\
(0.355)\end{array}$ & $\begin{array}{c}-1.203^{* *} \\
(0.342)\end{array}$ & $\begin{array}{c}-1.176^{* *} \\
(0.325)\end{array}$ & $\begin{array}{c}-0.768^{* *} \\
(0.362)\end{array}$ \\
\hline Relative teacher wage & $\begin{array}{c}-0.656^{* *} \\
(0.171)\end{array}$ & $\begin{array}{c}-0.639^{* *} \\
(0.179)\end{array}$ & $\begin{array}{c}-0.324^{* *} \\
(0.163)\end{array}$ & $\begin{array}{c}-0.520^{* *} \\
(0.193)\end{array}$ & $\begin{array}{c}-0.517^{* *} \\
(0.189)\end{array}$ & $\begin{array}{c}-0.176 \\
(0.262)\end{array}$ \\
\hline \multicolumn{7}{|l|}{ First Stage } \\
\hline Compulsory attendance $=9$ & & & & $\begin{array}{l}0.180^{* *} \\
(0.046)\end{array}$ & $\begin{array}{l}0.180^{* *} \\
(0.049)\end{array}$ & $\begin{array}{l}0.056^{* *} \\
(0.039)\end{array}$ \\
\hline Compulsory attendance $=10$ & & & & $\begin{array}{l}0.299^{* *} \\
(0.056)\end{array}$ & $\begin{array}{l}0.300^{* *} \\
(0.060)\end{array}$ & $\begin{array}{l}0.162^{*} \\
(0.047)\end{array}$ \\
\hline Compulsory attendance $\geq 11$ & & & & $\begin{array}{l}0.328^{* *} \\
(0.067)\end{array}$ & $\begin{array}{l}0.328^{* *} \\
(0.072)\end{array}$ & $\begin{array}{l}0.084^{* *} \\
(0.053)\end{array}$ \\
\hline F-statistic for excluded instruments & & & & 10.89 & 9.50 & 5.44 \\
\hline \multicolumn{7}{|l|}{ Controls: } \\
\hline age $\times$ offense effects & $\mathrm{y}$ & $\mathrm{y}$ & $\mathrm{y}$ & $\mathrm{y}$ & $\mathrm{y}$ & $\mathrm{y}$ \\
\hline offense $\times$ year effects & $\mathrm{y}$ & $\mathrm{y}$ & $\mathrm{y}$ & $\mathrm{y}$ & $\mathrm{y}$ & $\mathrm{y}$ \\
\hline age $\times$ year effects & $\mathrm{y}$ & $\mathrm{y}$ & $\mathrm{y}$ & $\mathrm{y}$ & $\mathrm{y}$ & $\mathrm{y}$ \\
\hline state $\times$ year effects & $\mathrm{y}$ & $\mathrm{y}$ & $\mathrm{y}$ & $\mathrm{y}$ & $\mathrm{y}$ & $\mathrm{y}$ \\
\hline state $\times$ offense effects & $\mathrm{y}$ & $\mathrm{y}$ & $\mathrm{y}$ & $\mathrm{y}$ & $\mathrm{y}$ & $\mathrm{y}$ \\
\hline state $\times$ offense $\times$ year effects & & $\mathrm{y}$ & $\mathrm{y}$ & & $\mathrm{y}$ & $\mathrm{y}$ \\
\hline state $\times$ broad age group & & & $\mathrm{y}$ & & & $\mathrm{y}$ \\
\hline
\end{tabular}

Notes: The dependent variable is the logarithm of the arrest rate by age, type of offense, state, and year. Average years of schooling is by age group, state, and year. All models control for the percentage black. There are eight age groups: $20-24,25-29,30-34,35-39,40-44,45-49,50-54$, and 55-59. There are 50 states plus the District of Columbia and four years 1960, 1970, 1980, and 1990. All models are weighted by cell size calculated as the number of women in each cell from the Census. The F-test for excluded instruments is distributed $F_{(3,1354)}$. Standard errors for state-year-age clustering are in parentheses. ${ }^{* *}$ p-value $<0.05 .{ }^{*}$ p-value $<0.10$. 
bearing decisions ${ }^{44}$ The results in Section 4.3 suggest that impacts on family structure are likely to be particularly strong for women.

Using our Census data, we estimate the effects of school quality and attainment on these different intermediate outcomes for white women based on IV specifications analogous to those reported in column 3 of Table 11. Compulsory schooling laws serve as instruments for educational attainment, while school quality measures are assumed to be exogenous. By examining the effects of both quality and attainment simultaneously, our effects of the former now reflect direct impacts holding attainment constant.

We begin with a discussion of female labor supply decisions and earnings. Table 15 shows modest (but statistically significant) negative effects of schooling attainment on labor supply and statistically insignificant negative effects on earnings. Changes in school quality have no direct effects on employment decisions, while a 10 day increase in school term length would lead to a modest (but statistically significant) increase in weeks worked and earnings. During our sample period (1960-1980), it appears unlikely that education reduced crime among women by encouraging them to participate more in the labor market.

Due to assortative mating in marriage markets (Becker, 1991), education should improve women's marital prospects. Evidence from twin studies suggest that an additional year of schooling raises that of a woman's spouse by 0.2-0.4 years (Behrman and Rosenzweig, 2002; Oreopoulos and Salvanes, 2011). Using quarter of birth as an instrument for own schooling attainment, Lefgren and McIntyre (2006) estimate negligible effects of women's schooling on the likelihood of marriage but significantly positive effects on husband's earnings. An extra year of education results in an additional $\$ 4,000$ in spousal earnings. These additional resources and the family stability that likely comes with them may help explain the significant reductions in crime associated with educational attainment among women. The effects of education on spousal quality may also be important due to changes in social networks, creation of social bonds, and/or exercise of informal social control (Sampson and Laub, 1990; Laub et al., 1998; Warr, 1998; Sampson et al., 2006).

Table 15 reports estimated effects of women's schooling and school quality on the probability of marriage, whether they are married to a high school graduate, and spousal earnings (set to zero if a woman is single) using compulsory schooling laws as instruments for attainment. The estimated effects of attainment are quite large, suggesting that an additional year of schooling increasing the probability of marriage by 7.5 percentage points, the probability of marrying a high school graduate by 16.5 percentage points, and spousal earnings by over $\$ 6,500$ per year; however, they should be read as upper bounds on the true effects. Because

\footnotetext{
${ }^{44}$ Schooling may also alter preferences for risk, self-control, or time discounting. See Oreopoulos and Salvanes (2011) for a recent survey of evidence on the broad ranging impacts of education on individuals.
} 


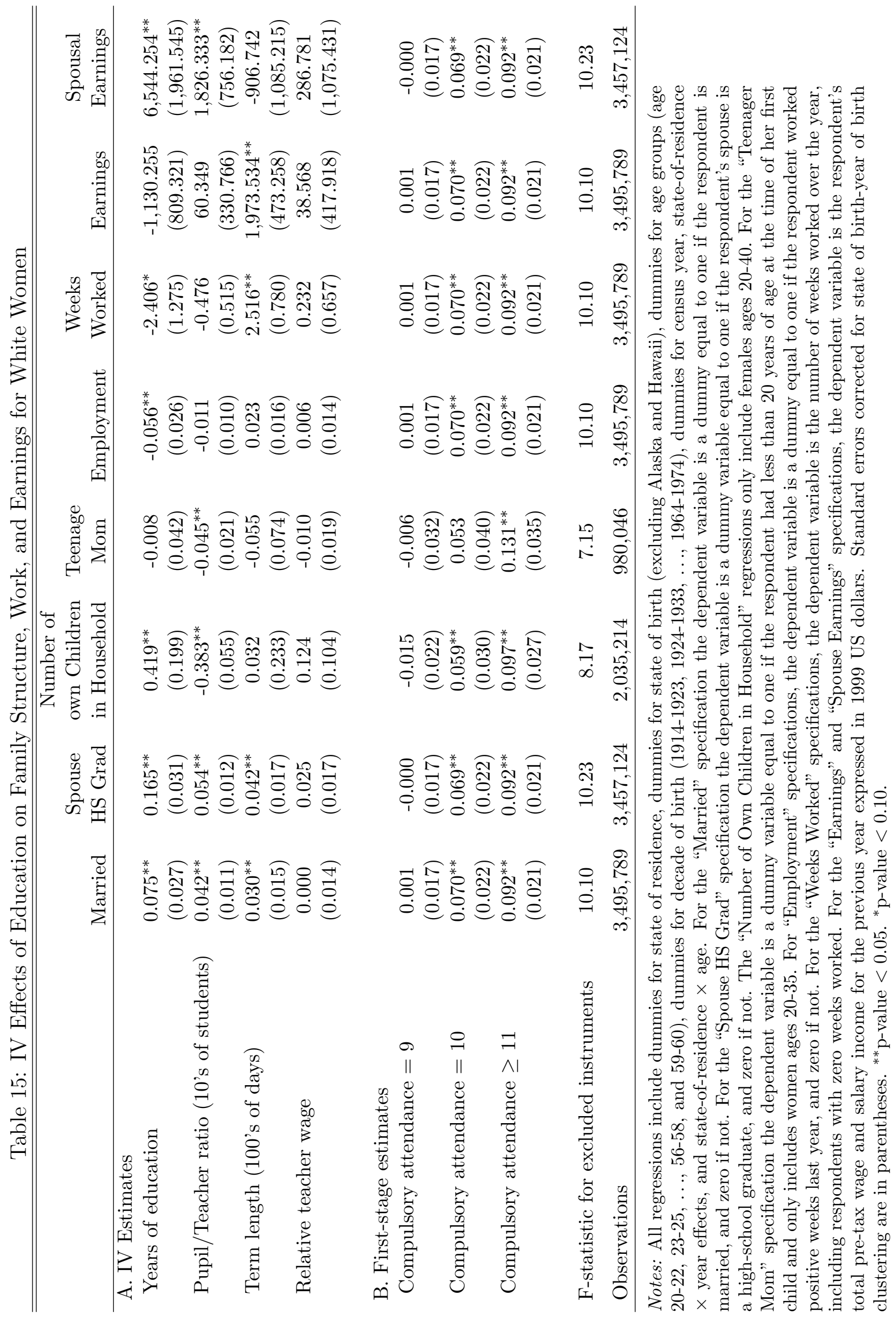


changes in the schooling laws impacted marriage matching functions (see Section 4.3), especially the probability of marriage, the estimated effects on these measures are likely to be biased upwards. Based on the findings reported in Table 8, the bias for marriage is likely to be sizeable; however the bias for spousal education should be more modest given the small effects of schooling laws on spousal education conditional on a woman's own schooling. Comparing our estimated effect on spousal earnings with that of Lefgren and McIntyre (2006) also suggests an upward bias. School quality measures have mixed effects on marriage outcomes with reductions in pupil/teacher ratios lowering marriage rates and the probability of marrying a high school graduate, while increasing term length has the opposite effects.

Finally, we explore the effects of schooling attainment and quality on fertility behavior. The IV results in Table 15 indicate that an additional year of schooling significantly increases the number of own children in the household by 0.42 for white women. Reductions in class size also increase the number of children in the household. We find no effect of educational attainment on the likelihood of becoming a teenage mother; however, reductions in pupil/teacher ratios appears to increase the probability 45

\section{Conclusions}

This paper provides some of the first evidence that increases in compulsory schooling laws, school quality (as measured by pupil-teacher ratios, term length, and teacher wage rates), and educational attainment can lead to significant reductions in female crime. Using compulsory schooling laws as instruments for education, we show that an additional year of schooling reduces the probability of incarceration by .05-.09 percentage points among white women. We also estimate that a one-year increase in average schooling levels reduces female arrest rates for both violent and property crime by more than $50 \%$, while there is little impact on white collar crime. The estimated direct effects of school quality measures are more mixed depending on the measure of quality and whether we look at arrests or incarceration. The indirect effects of quality improvements through increased schooling are positive for all quality measures but are generally modest in size.

Our IV estimates of the impacts of educational attainment are quite large, much larger than analogous OLS estimates. This is somewhat surprising, since most theories of crime suggest that OLS estimates should be biased towards finding too large an effect. One important concern is the possibility that changes in schooling laws were contemporaneous with

\footnotetext{
${ }^{45}$ Estimates for the number of children in the household are based on women ages 20-40 to measure cumulative fertility while ensuring that the vast majority of children should still be living at home. Estimates for teen motherhood are based on women ages 20-35 to ensure that children born when mothers were teenagers would still be living at home.
} 
other major changes in the education system, which could bias our IV estimates Stephens and Yang, 2014). Fortunately, our main IV estimates are very similar whether or not we control for state- and cohort-specific school quality levels as measured by pupil-teacher ratios, term length, and teacher pay. Furthermore, we account for any differences in enforcement policies and labor market conditions across states over time by controlling for state-specific year effects. While our IV estimates are likely inflated due to effects of minimum schooling laws on marriage markets (via increases in aggregate education levels among both men and women), our estimates that control for direct impacts of marriage on incarceration suggest that any bias from this is likely to be quite modest. Instead, the much stronger effects of education on crime obtained using IV rather than OLS estimation is most likely due to heterogeneity in effects of schooling across individuals and grade levels. Our results are consistent with particularly strong impacts of schooling on crime among women that are most responsive to changes in schooling laws, especially those that would otherwise drop out of high school.

It is interesting to compare our results with the estimated impacts of education on incarceration and arrests among men. Analogous IV estimates of the impact of an additional year of schooling on the probability of incarceration are about four times higher for men than women, while baseline incarceration rates are roughly 20 times higher for low-educated men vs. women. Thus, the impact of education on imprisonment is much stronger for women in percentage terms. This is also true for arrest rates, where analogous IV estimates for men suggest that a one-year increase in average education levels would reduce arrests by only $5-10 \% 46$ Given the low baseline crime rates among women, a policy aimed at raising male education levels would have greater impacts on aggregate crime rates than one targeting female crime rates. However, the latter is likely to be more transformative for women as a group, than the former would be for men.

Finally, we explore the channels through which education may affect female crime. Lochner and Moretti (2004) argue that, among men, most of the effect of education on crime can be explained by increases in wages and greater labor market participation 47 Our results suggest that this is not the case for women (at least from 1960-1980), since we find little effect of schooling on female labor supply behavior. Instead, education appears to improve the marital prospects of women. The accompanying increases in marriage likely

\footnotetext{
${ }^{46}$ See Online Appendix Tables D-7 and D-8 for estimated effects of schooling on male incarceration and arrests, respectively, analogous to those reported in Tables 10 and 13 . Also see Lochner and Moretti (2004) for related results for men.

${ }^{47} \mathrm{IV}$ estimates for men analogous to those reported in Table 15 (without school quality controls) suggest that an additional year of schooling raises their employment rates by 3.6 percentage points, weeks worked by 3.1 , and annual earnings by $\$ 4,811$ (all statistically significant), while it has no significant effect on spousal earnings.
} 
reduce crime by strengthening family bonds, while increases in spousal education and family resources may limit the incentives for women to turn to crime in order to support the family. Still, we find that education reduces incarceration even when conditioning on marital status, so other channels are also important. We find that increased schooling causes women to have more children, which may discourage crime by raising the personal costs of time in prison and strengthening family/social bonds. Education may also reduce crime by changing women's preferences for risk or self-control.

Of course, the channels through which education impacts female crime may have changed in more recent decades as women have increasingly entered the labor market, reduced their time at home, and raised fewer children. This is an interesting avenue for future research. 


\section{References}

Acemoglu, D. and J. Angrist (2001, January). How large are human-capital externalities? evidence from compulsory-schooling laws. In B. S. Bernanke and K. Rogoff (Eds.), NBER Macroeconomics Annual 2000, Volume 15. MIT PRess.

Becker, G. (1964). Human Capital. New York: Columbia University Press.

Becker, G. S. (1968). Crime and punishment: An economic approach. Journal of Political Economy 76(2), 169-217.

Becker, G. S. (1991). A Treatise on the Family (Enlarged ed.). Harvard University Press.

Behrman, J. and M. Rosenzweig (2002). Does increasing women's schooling raise the schooling of the next generation? American Economic Review 92(1), 323-334.

Bell, B., R. Costa, and S. Machin (2016). Crime, compulsory schooling laws and education. Economics of Education Review 54, 214-226.

Blundell, R. and T. MaCurdy (1999). Labor supply: A review of alternative approaches. In O. C. Ashenfelter and D. Card (Eds.), Handbook of Labor Economics, Volume 3A, Chapter 27, pp. 1559 - 1695. Amsterdam: Elsevier.

Card, D. and A. Krueger (1992a). Does school quality matter? Returns to education and the characteristics of public schools in the united states. Journal of Political Economy 100(1), $1-40$.

Card, D. and A. B. Krueger (1992b). School quality and black-white relative earnings: A direct assessment. Quarterly Journal of Economics 107(1), 151-200.

Cullen, J., B. Jacob, and S. Levitt (2006). The Effect of School Choice on Participants: Evidence from Randomized Lotteries. Econometrica 74, 1191-1230.

Deming, D. (2011). Better schools, less crime? Quarterly Journal of Economics 126, 20632115.

Ehrlich, I. (1975). On the Relation Between Education and Crime. In F. T. Juster (Ed.), Education, Income, and Human Behavior, Chapter 12. New York: McGraw-Hill Book Co.

Engelhardt, B., G. Rocheteau, and P. Rupert (2008). The labor market and female crime. In P. Rupert (Ed.), Frontiers of Family Economics, Volume 1, Chapter 4, pp. 139-163. Emerald Group Publishing Limited. 
Freeman, R. (1996). Why Do So Many Young American Men Commit Crimes and What Might We Do About It? Journal of Economic Perspectives 10, 25-42.

Freeman, R. (1999). The Economics of Crime. In O. Ashenfelter and D. Card (Eds.), Handbook of Labor Economics, Volume 3C, Chapter 52. Amsterdam: Elsevier, Science B.V.

Gould, E., D. Mustard, and B. Weinberg (2002). Crime Rates and Local Labor Market Opportunities in the United States: 1977-1997. Review of Economics and Statistics 84, 45-61.

Grogger, J. (1998). Market Wages and Youth Crime. Journal of Labor Economics 16, 756-91.

Hanushek, E. A. (2002). Publicly provided education. In A. J. Aurbach and M. Feldstein (Eds.), Handbook of Public Economics, Volume 4, pp. 2045-2141. Amsterdam: Elsevier.

Heckman, J., A. Layne-Farrar, and P. Todd (1996). Human capital pricing equations with an application to estimating the effect of schooling quality on earnings. Review of Economics and Statistics 78(4), 562-610.

Heckman, J. J. and R. J. Robb (1985). Alternative methods for evaluating the impact of interventions. In J. Heckman and B. Singer (Eds.), Longitudinal Analysis of Labor Market Data, pp. 156-246. Cambridge: Cambridge UniversityPress.

Heckman, J. J. and R. J. Robb (1986). Alternative methods for solving the problem of selection bias in evaluating the impact of treatments on outcomes. In H. Wainer (Ed.), Drawing Inferences from Self-Selected Samples, pp. 63-107. New York: Springer-Verlag.

Heller, S. B., B. A. Jacob, and J. Ludwig (2011). Family income, neighborhood poverty, and crime. In P. J. Cook, J. Ludwig, and J. McCrary (Eds.), Controlling Crime: Strategies and Tradeoffs, pp. 419-459. Chicago: University of Chicago Press.

Hjalmarsson, R., H. Holmlund, and M. J. Lindquist (2015). The effect of education on criminal convictions and incarceration: Causal evidence from micro-data. Economic Journal 125(587), 1290-1326.

Hjalmarsson, R. and L. Lochner (2012). The impact of education on crime: International evidence. CESifo DICE Report 10(2), 49.

Imbens, G. and J. Angrist (1994). Identification and estimation of local average treatment effects. Econometrica 62(2), 467-475. 
Laub, J. H., D. S. Nagin, and R. J. Sampson (1998). Trajectories of change in criminal offending: Good marriages and the desistance process. American Sociological Review 63(2), $225-238$.

Lefgren, L. and F. McIntyre (2006). The relationship between women's education and marriage outcomes. Journal of labor Economics 24(4), 787-830.

Lochner, L. (2004). Education, Work, and Crime: A Human Capital Approach. International Economic Review 45(3), 811-43.

Lochner, L. (2010). Education policy and crime. In P. Cook, J. Ludwig, and J. McCrary (Eds.), Controlling crime: Strategies and tradeoffs, Chapter 10, pp. 465-515. Chicago: University of Chicago Press.

Lochner, L. (2011). Nonproduction benefits of education: Crime, health, and good citizenship. In E. Hanushek, S. Machin, and L. Woessmann (Eds.), Handbook of the Economics of Education, Volume 4, Chapter 2, pp. 183-282. Elsevier.

Lochner, L. and E. Moretti (2004, March). The effect of education on crime: Evidence from prison inmates, arrests, and self-reports. American Economic Review 94(1), 155-189.

Lochner, L. and E. Moretti (2015). Estimating and testing models with many treatment levels and limited instruments. Review of Economics and Statistics 97(2), 387-397.

Machin, S., O. Marie, and S. Vujić (2011). The crime reducing effect of education. Economic Journal 121(552), 463-484.

Machin, S. and C. Meghir (2004). Crime and Economic Incentives. Journal of Human Resources 39, 958-79.

Oreopoulos, P. and K. Salvanes (2011). Priceless: The nonpecuniary benefits of schooling. The Journal of Economic Perspectives 25(1), 159-184.

Sampson, R. J. and J. H. Laub (1990). Crime and deviance over the life course: The salience of adult social bonds. American Sociological Review 55(5), 609-627.

Sampson, R. J., J. H. Laub, and C. Wimer (2006). Does marriage reduce crime?: A counterfactual approach to within-individual causal effects. Criminology 44(3), 465-508.

Schwartz, J. and D. Steffensmeier (2007). The nature of female offending: Patterns and explanation. In R. Zaplin (Ed.), Female Offenders: Critical Perspectives and Effective Interventions (Second ed.)., Chapter 2, pp. 43-75. Boston, MA: Jones and Bartlett. 
Staiger, D. and J. Stock (1997). Instrumental variables regression with weak instruments. Econometrica 65(3), 557-586.

Steffensmeier, D. and C. Streifel (1992, March). Time-series analysis of the female percentage of arrests for property crimes, 1960-1985: A test of alternative explanations. Justice Quarterly 9(1), 77-104.

Stephens, M. and D.-Y. Yang (2014). Compulsory education and the benefits of schooling. American Economic Review 104(6), 1777-1792.

Tittle, C. R., W. J. Villemez, and D. A. Smith (1978). The myth of social class and criminality: An empirical assessment of the empirical evidence. American Sociological Review, 643-656.

Warr, M. (1998). Life-course transitions and desistance from crime. Criminology 36(2), $183-216$.

Weiner, D., B. Lutz, and J. Ludwig (2009). The Effects of School Desegregation on Crime. NBER Working Paper Paper No. 15380. 


\section{APPENDIX}

\section{A Detailed Data Description}

\section{A.1 Analysis of Education and Incarceration}

For our analysis of incarceration, we use Census data from the 1960, 1970, and 1980 US Censuses. The Census data is obtained from the Integrated Public Use Microdata Series (IPUMS): (i) 1 percent sample of the 1960 US Census, (ii) 1 percent state samples of the 1970 US Census, Form 1 and Form 2, and (iii) 5 percent state sample of the 1980 US Census.

The sample only includes black or white females ages 20-60 who were born in the 48 contiguous states (i.e. excludes Alaska and Hawaii). The indicator for incarceration is based on the variable for the group quarters type, set to one if the respondent is in a correctional institution and zero otherwise. Years of schooling are based on the highest grade of schooling completed (nursery and kindergarten are considered as zero years of schooling).

Table A-1 presents descriptive statistics for key variables in our sample of 20-60 year-old women from the US Censuses. Over the 1960-80 period, about .02 percent of white women and .1-.15 percent of black women were in prison at the time of the Censuses. Average education increased by 1.6 years for whites and 2.8 years for blacks.

Table A-1: Descriptive Statistics for Census Data by Year: Mean (Standard Deviation)

\begin{tabular}{|c|c|c|c|c|c|c|}
\hline \multirow[b]{2}{*}{ Variable } & \multicolumn{3}{|c|}{ White Females } & \multicolumn{3}{|c|}{ Black Females } \\
\hline & 1960 & 1970 & 1980 & 1960 & 1970 & 1980 \\
\hline \multirow[t]{2}{*}{ Incarcerated (in percent) } & 0.019 & 0.015 & 0.022 & 0.131 & 0.107 & 0.145 \\
\hline & $(1.363)$ & $(1.219)$ & $(1.490)$ & $(3.620)$ & $(3.277)$ & $(3.810)$ \\
\hline \multirow[t]{2}{*}{ Years of Schooling } & 10.854 & 11.593 & 12.431 & 8.707 & 10.057 & 11.528 \\
\hline & $(2.893)$ & $(2.737)$ & $(2.625)$ & $(3.588)$ & $(3.300)$ & $(2.938)$ \\
\hline \multirow[t]{2}{*}{ High School Graduate } & 0.547 & 0.672 & 0.795 & 0.271 & 0.424 & 0.634 \\
\hline & $(0.498)$ & $(0.469)$ & $(0.404)$ & $(0.445)$ & $(0.494)$ & $(0.482)$ \\
\hline \multirow[t]{2}{*}{ Age } & 38.953 & 38.685 & 37.530 & 38.035 & 37.583 & 36.149 \\
\hline & $(11.226)$ & $(12.066)$ & $(12.089)$ & $(11.255)$ & $(11.799)$ & $(11.812)$ \\
\hline Sample size & 366,070 & 807,787 & $2,439,456$ & 43,452 & 96,745 & 340,512 \\
\hline
\end{tabular}

Notes: Census data obtained from the Integrated Public Use Microdata Series (IPUMS) using the US

Census of: 1960 1\% sample, 1970 Form 1 and Form 2 State 1\% samples, and 1980 5\% sample.

The analysis includes dummies for 14 age groups: 20-22, 23-25,.., 56-58, and 59-60. When we control for state-specific broad age categories, these are based on ages 20-34, 3549, and 50-60. We also include six birth cohort dummies for women born in 1914-1923, 1924-1933, 1934-1943, 1944-1953, 1954-1963, and 1964-1974. 
These data are merged with data on compulsory attendance laws based on two variables: (i) the state of birth of the respondent, and (ii) the year in which the respondent was age 14 . As in Acemoglu and Angrist (2001) and Lochner and Moretti (2004), we define compulsory attendance as the maximum between (i) the minimum number of years that a child is required to stay in school and (ii) the difference between the earliest age that she is required to be in school and the latest age she is required to enroll. We create three indicator variables for states with compulsory schooling laws that require: (i) 9 years of schooling, (ii) 10 years of schooling, and (iii) 11 or more years of schooling. The omitted category in the analysis is those states requiring 8 or less years of schooling. For further details about these data, see Acemoglu and Angrist (2001) and Lochner and Moretti (2004).

Finally, these data are merged with measures of school quality based on two variables: (i) the state of birth of the respondent and (ii) the year of birth of the respondent. The measures of quality are: (i) pupil/teacher ratios, (ii) school term length, and (iii) relative teacher salaries. Pupil/teacher ratios are re-scaled to reflect the number of pupils per teacher divided by 10. School term length is scaled to reflect hundreds of days. Teacher salaries are relative to the national average teacher salary, which is obtained for each year by taking a simple average over all state average salaries. For each year of birth, these measures correspond to average quality for public schools in their state of birth over the years in which the respondent was ages 6-17 (elementary and secondary school). For further details on these data, see Card and Krueger (1992a) and Stephens and Yang (2014).

\section{A.2 Data for Analysis of Education and Arrest Rates}

The data on female arrests is obtained from the FBI Uniform Crime Reports (UCR) for years 1960, 1970, 1980, and 1990. We compute the arrest counts by state, year, offense, and age group for females. The offenses considered in the analysis are those for violent, property, and white collar crimes. The violent crime offenses considered in the analysis include: murder and non-negligent manslaughter, robbery, and aggravated assault. The property crime offenses considered include: burglary - breaking or entering, larceny - theft (except motor vehicle), motor vehicle theft, and arson. The white collar crime offenses considered include: forgery and counterfeiting, fraud, and embezzlement. We use arrest counts for women ages 20-59 grouped as follows: ages 20-24, ages 25-29,.., age 55-59. Since the UCR data only contain population counts by state and year (not separately by age group), we must merge these data with Census data to determine age-specific arrest rates.

The data on arrest counts are merged with Census data for years 1960, 1970, 1980, and 1990. The Census data for 1960-1980 correspond to the same samples explained in Appendix 
A.1. while we use the 5 percent sample (with sample weights) for 1990. From the Censuses, we can compute the age distribution among the relevant female population, which can then be multiplied by the population covered by state-year in the UCR to calculate population counts by age, state, and year. We then divide the UCR arrest counts (by offense, age, state, and year) by the population counts (by age, state, and year) to create the arrest rate measures used in our analysis.

From the Census data, we obtain measures of average years of completed education, high school graduation rates, and the fraction black by year, state, and age group, where the age groups match those from the UCR data. These measures are un-weighted for years 1960, 1970, and 1980, and are weighted using the Census sampling weights for 1990. Females from all races are included when computing these measures. Since schooling is only reported in intervals for grades 1-4 and 5-8 in the 1990 Census, we use average years of schooling within these categories from the 1980 Census to assign years of schooling for 1990 respondents in these two categories.

To incorporate compulsory attendance laws and school quality into the analysis of arrest rates, we merge the Census data at the individual level with the compulsory attendance laws and with the school quality data following the exact same procedure as described in Appendix A.1. That is, we assign compulsory attendance laws for each woman based on the year in which she was age 14 and her state of birth. Similarly, we assign school quality measures for each woman based on her year of birth and her state of birth. Once these measures are assigned to the female respondents in the Census, we obtain averages of these measures by year, state of residence, and age group. Notice that in this case, the compulsory attendance laws are no longer indicator variables. Instead, they reflect the probability that a women from age group $a$ living in state $l$ in year $t$ was born in a state that had a specific schooling law when she was age 14. In this way, we account for inter-state migration patterns and exploit the actual experiences of women in terms of their schooling laws and school quality.

Finally, the UCR arrest data is merged with the averaged Census data (which contains the averaged compulsory attendance laws and school quality measures) based on year, state, and age group. The Census data also contains the number of females in each cell, which is used as a weight in all regressions.

\section{B Additional Model Details}

This appendix provides additional details for the model described in Section 2 . 


\section{B.1 Reduced-Form Effects of School Quality}

The reduced-form effects of school quality on crime for women are given by:

$$
\frac{d c}{d Q}=\beta^{m}(s, L, Q) \frac{\partial S}{\partial Q}+m\left(\frac{\partial C^{1}}{\partial Y} \frac{\partial \tilde{y}}{\partial \tilde{s}} \frac{\partial \tilde{S}}{\partial \theta} \frac{\partial \theta}{\partial Q}\right)+\frac{\partial C^{m}}{\partial w} \frac{\partial w}{\partial Q}+\frac{\partial C^{m}}{\partial Y} \frac{\partial y}{\partial Q}+\frac{\partial C^{m}}{\partial Q}, \quad m \in\{0,1\}
$$

The effects of changes in school quality are similar to those of schooling laws with the addition of more direct effects of quality on crime that do not come through schooling (i.e. the final 3 terms above).

\section{B.2 IV Estimation}

For single women, if $E(\varepsilon \mid L, Q, m=0)=0$, an IV approach should yield consistent estimates of the average total effect of education on crime for single women, since

$$
\frac{E\left(\frac{d c}{d L} \mid L, Q, m=0\right)}{E\left(\frac{\partial s}{\partial L} \mid L, Q, m=0\right)}=E\left[\beta^{0}(s, L, Q) \mid L, Q, m=0\right]
$$

For married women, if either (i) the income effects on crime are zero, $\frac{\partial C^{1}}{\partial Y}=0$, or (ii) changes in schooling laws do not alter spousal schooling levels except through changes in women's own schooling, $\frac{\partial \tilde{S}}{\partial \theta} \frac{\partial \theta}{\partial L}=0$, and if $E(\varepsilon \mid L, Q, m=1)=0$, then

$$
\frac{E\left(\frac{d c}{d L} \mid L, Q, m=1\right)}{E\left(\frac{d s}{d L} \mid L, Q, m=1\right)}=E\left[\beta^{1}(s, L, Q) \mid L, Q, m=1\right]
$$

and an IV approach should yield consistent estimates of the average total effect of education on crime.

Next, consider average crime among all women regardless of their marital status. For $\xi \sim F_{\xi}(\cdot)$ (pdf given by $f_{\xi}(\cdot)$ ), the probability a woman with schooling level $s$ under laws $L$ and quality $Q$ is married is given by

$$
P(s, L, Q) \equiv F_{\xi}(M(s, \theta(L, Q)))
$$

The total effect of a change in schooling laws on the marriage probability for someone is given by

$$
\frac{d P}{d L}=f_{\xi}(M)\left[\frac{\partial M}{\partial s} \frac{\partial S}{\partial L}+\frac{\partial M}{\partial \theta} \frac{\partial \theta}{\partial L}\right]=\frac{\partial P}{\partial s} \frac{\partial S}{\partial L}+f_{\xi}(M) \frac{\partial M}{\partial \theta} \frac{\partial \theta}{\partial L},
$$

where $\frac{\partial P}{\partial s}=f_{\xi}(M) \frac{\partial M}{\partial s}$ reflects the partial effect of changing a woman's schooling on her 
probability of marriage. The difference between the total and partial effects captures the influence of schooling laws on the equilibrium matching function through changes in the distributions of schooling among men and women.

The effect of a change in schooling laws on crime is given by: 48

$\frac{d E[c \mid L, Q]}{d L}=E[\bar{\beta} \mid L, Q] \frac{\partial S}{\partial L}+E\left[P(s, L, Q) \frac{\partial C^{1}}{\partial Y} \frac{\partial \tilde{y}}{\partial \tilde{s}} \frac{\partial \tilde{S}}{\partial \theta}+f_{\xi}(M) \frac{\partial M}{\partial \theta} \Delta(w, Y, s, Q) \mid L, Q\right] \frac{\partial \theta}{\partial L}$

The last term reflects two potential sources of bias that can arise when using schooling laws as an instrument for schooling in our context. Both derive from impacts of schooling laws on the distribution of education for men and women, which may alter the marriage market matching function. First, changes in the matching function can impact which type of man any given woman might marry conditional on her educational attainment. Second, changes in the marriage matching function might affect whether women decide to marry at all (conditional on their education). If family income and marriage both reduce crime $\left(\frac{\partial C^{1}}{\partial Y}<0\right.$ and $\left.\Delta<0\right)$ and increased mandatory schooling raises marriage rates and improves the education distribution of spouses, then estimated (negative) effects of own-schooling on crime are likely to be exaggerated when using schooling laws as instruments.

The following two assumptions eliminate bias due to schooling's effect on marriage rates through changes in marriage markets.

Assumption 1. (i) $\frac{\partial C^{1}}{\partial Y}=0$ (no income effects on crime for married women), and/or (ii) $\frac{\partial \tilde{S}}{\partial \theta} \frac{\partial \theta}{\partial L}=0$ (no effect of schooling laws on marriage matching functions).

Assumption 2. (i) $\Delta(w, Y, s, Q)=0$ (no direct effects of marriage on crime), and/or (ii) $\frac{\partial M}{\partial \theta} \frac{\partial \theta}{\partial L}=0$ (no effect of schooling laws on marriage rates).

Assumption 1 is specific to the bias that is arises from the sub-sample of married women, whereas Assumption 2 is for the bias in the full sample of women. Together, Assumptions 1 and 2 yield:

$$
\frac{E\left(\frac{d c}{d L} \mid L, Q\right)}{E\left(\frac{d S}{d L} \mid L, Q\right)}=E[\bar{\beta} \mid L, Q] .
$$

IV estimation (using schooling laws as instruments) will produce consistent estimates of the average total effect of own schooling on crime if marital decisions are unaffected by changes in schooling distributions (i.e. $\partial \theta / \partial L=0$ ) or if there are no income or marriage effects on crime.

\footnotetext{
${ }^{48}$ As above, the effects of changes in school quality would be similar to those of schooling laws with the addition of more direct effects of quality on crime that do not come through schooling.
} 


\section{B.3 Special Case: No Effects of Marriage on Crime}

The special case where marriage itself has no direct effects on crime (i.e. $C^{1}(w, Y, s, Q)=$ $\left.C^{0}(w, Y, s, Q)=\bar{C}(w, Y, s, Q)\right)$ allows for some additional simplifications and a useful bound expression for the IV bias. In this case,

$$
\beta^{1}(s, L, Q)=\beta^{0}(s, Q)+\frac{\partial \bar{C}}{\partial Y} \frac{\partial \tilde{y}}{\partial \tilde{s}} \frac{\partial \tilde{S}}{\partial s}
$$

and

$$
\bar{\beta}(s, L, Q)=\beta^{0}(s, Q)+P(s, L, Q) \frac{\partial \bar{C}}{\partial Y} \frac{\partial \tilde{y}}{\partial \tilde{s}} \frac{\partial \tilde{S}}{\partial s} .
$$

Assuming that crime is weakly decreasing in family income $\left(\frac{\partial \bar{C}}{\partial Y} \leq 0\right)$ and that spousal education is weakly increasing in own education $\left(\frac{\partial \tilde{S}}{\partial s} \geq 0\right)$, we can order the total effects on crime as follows: $\beta^{1}(s, L, Q) \leq \bar{\beta}(s, L, Q) \leq \beta^{0}(s, Q)$. When marriage has no direct effect on crime, schooling should have stronger negative effects on married relative to single women the difference reflects the impact of higher family income from a more educated spouse ${ }^{49}$

The IV estimator (using schooling laws as instruments) now identifies

$$
\frac{E\left(\frac{d c}{d L} \mid L, Q\right)}{E\left(\frac{d s}{d L} \mid L, Q\right)}=E[\bar{\beta}(s, L, Q) \mid L, Q]+E\left[P(s, L, Q) \frac{\partial \bar{C}}{\partial Y} \frac{\partial \tilde{y}}{\partial \tilde{s}} \frac{\partial \tilde{S}}{\partial \theta} \mid L, Q\right] \frac{\partial \theta}{\partial L} / \frac{\partial S}{\partial L},
$$

which may still be biased due to changes in spousal income coming from impacts of schooling laws on marriage matching functions. The 'income effect' on crime is inflated when the laws lead to higher spousal education conditional on the woman's own education. This bias should be small when marriage rates are low, changes in marital sorting patterns are modest, or the effects of schooling on male earnings are weak.

If $\bar{C}$ is non-increasing in wages, household income, and schooling, then a negative IV estimate implies that $\bar{\beta}(s, L, Q)<0$, since negative effects from higher spousal income must be accompanied by negative effects of higher own income. Indeed, we can bound the extent to which any marital matching effects bias our estimates if there is positive assortative mating (i.e. $\frac{\partial \tilde{S}}{\partial s} \geq 0$ ).

To see this, first assume that wages and education have no direct effects on crime (i.e. $\frac{\partial \bar{C}}{\partial w}=\frac{\partial \bar{C}}{\partial s}=0$ ), so schooling only affects female crime through family income. Then, the total

\footnotetext{
${ }^{49}$ The result that $\beta^{1}<\beta^{0}$ holds more generally as long as $\Delta(w, Y, s, Q)=\bar{\Delta}$ is a constant; however, $\bar{\beta}$ need not be a weighted average of $\beta^{0}$ and $\beta^{1}$ in this case.
} 
effect of schooling on expected crime reduces to

$$
\bar{\beta}(s, L, Q)=\frac{\partial \bar{C}}{\partial Y}\left[\frac{\partial y}{\partial s}+P(s, L, Q) \frac{\partial \tilde{y}}{\partial \tilde{s}} \frac{\partial \tilde{S}}{\partial s}\right]
$$

Finally, if $\frac{\partial \bar{C}}{\partial Y}$ does not vary conditional on $(L, Q)$, then

$$
\frac{E\left(\frac{d c}{d L} \mid L, Q\right) / E\left(\frac{d s}{d L} \mid L, Q\right)}{E[\bar{\beta}(s, L, Q) \mid L, Q]}=1+\frac{E\left[P(s, L, Q) \frac{\partial \tilde{y}}{\partial \tilde{s}} \frac{\partial \tilde{S}}{\partial \theta} \mid L, Q\right] \frac{\partial \theta}{\partial L} / \frac{\partial S}{\partial L}}{E\left[\frac{\partial y}{\partial s}+P(s, L, Q) \frac{\partial \tilde{y}}{\partial \tilde{s}} \frac{\partial \tilde{S}}{\partial s} \mid L, Q\right]} \leq 1+\frac{d E[m \cdot \tilde{y} \mid L, Q] / d L}{d E[y \mid L, Q] / d L}
$$

The effect of schooling laws on expected spousal earnings (including zeros for single women) relative to own earnings can be used to bound the bias factor - the ratio of the IV estimator to the true total effect of education on crime 50 If wages and education reduce crime, including these additional terms would only increase $|\bar{\beta}(s, L, Q)|$, so this bound would continue to apply.

\section{Addressing Endogeneity and Sample Selection using 2SLS and Control Functions}

In this appendix, we combine the use of instrumental variables and a control function approach to address endogenous schooling and self-selection into marriage 51

Consider the following system of equations:

$$
\begin{aligned}
I_{i} & =s_{i} \gamma_{s}+X_{i}^{\prime} \gamma_{X}+\varepsilon_{i} \\
s_{i} & =S\left(X_{i}, Z_{s i}\right)+\eta_{i} \\
m_{i} & =\mathbb{1}\left[\xi_{i}<M\left(X_{i}, Z_{i}\right)\right] .
\end{aligned}
$$

where $Z_{s} \subseteq Z$ and $(\varepsilon, \eta, \xi) \Perp(X, Z)$. Denote the cdf for $\xi_{i}$ by $F_{\xi}(\cdot){ }^{52}$

${ }^{50}$ The inequality follows from $\frac{\partial \tilde{S}}{\partial s} \geq 0$ and

$$
\begin{aligned}
\frac{d E[m \cdot \tilde{y} \mid L, Q]}{d L} & =E\left[P(s, L, Q) \frac{\partial \tilde{y}}{\partial \tilde{s}} \frac{\partial \tilde{S}}{\partial s} \mid L, Q\right] \frac{\partial S}{\partial L}+E\left[P(s, L, Q) \frac{\partial \tilde{y}}{\partial \tilde{s}} \frac{\partial \tilde{S}}{\partial \theta} \mid L, Q\right] \frac{\partial \theta}{\partial L} \\
\frac{d E[y \mid L, Q]}{d L} & =E\left[\frac{\partial y}{\partial s} \mid L, Q\right] \frac{\partial S}{\partial L}
\end{aligned}
$$

${ }^{51}$ See Heckman and Robb 1985,1986$)$ for a general treatment of control functions.

${ }^{52}$ In our empirical analysis, we include quality $Q_{i}$ in $X_{i}$ along with all other covariates. Our schooling laws (when women were age 14) $L_{i}$ and quarter of birth indicators are included in both $Z_{s}$ and $Z$, while $Z$ 
We are mainly interested in estimating $\gamma_{s}$, where we want to do this for a sample conditional on $m_{i}=1$. Consider the main equations for 2SLS:

$$
\begin{aligned}
& E[I \mid X, Z, m=1]=X^{\prime} \gamma_{X}+E[s \mid X, Z, m=1] \gamma_{s}+E[\varepsilon \mid X, Z, m=1] \\
& E[s \mid X, Z, m=1]=S\left(X, Z_{s}\right)+E[\eta \mid X, Z, m=1] .
\end{aligned}
$$

Since $(\varepsilon, \eta, \xi) \Perp(X, Z)$,

$$
\begin{aligned}
& E\left[\varepsilon \mid X, Z, F_{\xi}(\xi)<F_{\xi}(M(X, Z))\right]=E[\varepsilon \mid P(X, Z)] \equiv K_{1}[P(X, Z)] \\
& E\left[\eta \mid X, Z, F_{\xi}(\xi)<F_{\xi}(M(X, Z))\right]=E[\eta \mid P(X, Z)] \equiv g_{1}[P(X, Z)],
\end{aligned}
$$

where $P(X, Z)=F_{\xi}(M(X, Z))$ is the propensity score. Defining $\hat{s}_{1}(X, Z) \equiv E[s \mid X, Z, m=$ 1], we can further write

$$
\begin{aligned}
E[I \mid X, Z, m=1] & =X^{\prime} \gamma_{X}+\hat{s}_{1}(X, Z) \gamma_{s}+K_{1}[P(X, Z)] \\
\hat{s}_{1}(X, Z) & =S\left(X, Z_{s}\right)+g_{1}[P(X, Z)] .
\end{aligned}
$$

Identification of $\gamma_{s}$ requires $X^{\prime} \gamma_{X}+\hat{s}_{1}(X, Z) \gamma_{s} \neq \lambda K_{1}[P(X, Z)]$ for any scalar $\lambda$. Substituting in for $\hat{s}_{1}(X, Z)$, identification requires:

$$
\left\{X^{\prime} \gamma_{X}+S\left(X, Z_{s}\right) \gamma_{s}\right\}+g_{1}[P(X, Z)] \gamma_{s} \neq \lambda K_{1}[P(X, Z)]
$$

This would be satisfied if we can independently vary the terms in braces by varying $X$ and $Z_{s}$, while holding $P(X, Z)$ and, therefore, $g_{1}[P(X, Z)]$ and $K_{1}[P(X, Z)]$, constant 53

In practice, these assumptions allow us to estimate $\gamma_{s}$ using a modified two-stage least squares (2SLS) approach as follows:

1. Preliminary: Estimate $\hat{P}(X, Z)$ based on equation 10$)$ for the full sample. In practice, we specify this as a probit (i.e. $\left.\xi \sim N\left(0, \sigma_{\xi}^{2}\right)\right)$ with index $M(X, Z)=X^{\prime} \mu_{X}+Z^{\prime} \mu_{Z}$.

2. First stage: Using the sample with $m=1$, obtain $\hat{s}_{1}(X, Z)$ from a regression of $s$ on $\left(X, Z_{s}\right)$ and a polynomial in $\hat{P}(X, Z)$. This is a simple linear regression if $S\left(X, Z_{s}\right)=$ $X^{\prime} \psi_{X}+Z_{s}^{\prime} \psi_{Z}$, which we use in practice.

also includes schooling laws when women were age 10 .

${ }^{53}$ In the special case where $S\left(X, Z_{s}\right)=X^{\prime} \psi_{X}+Z_{s}^{\prime} \psi_{Z}, M(X, Z)=X^{\prime} \mu_{X}+Z^{\prime} \mu_{Z}$, and with a single $X$ and single $Z=Z_{s}$, this requires

$$
\mu_{Z}\left(\gamma_{X}+\psi_{X} \gamma_{s}\right) \neq \mu_{X} \psi_{Z} \gamma_{s}
$$


3. Second stage: Using the sample with $m=1$, regress $I$ on $X, \hat{s}_{1}(X, Z)$, and a polynomial in $\hat{P}(X, Z)$.

Thus, after obtaining estimates $\hat{P}(X, Z)$ from the full sample, one can simply use a 2SLS approach on the selected sample where $I$ is regressed on $X, \hat{s}_{1}$, and a polynomial in $\hat{P}$ using the instruments $X, Z_{s}$, and polynomial in $\hat{P}$. Note that in estimating $\hat{P}$, the full set of instruments $(X, Z)$ are used, where $Z$ ideally contains some excluded variables not in $Z_{s}$. 


\section{Online Appendix}

\section{D.1 Alternative Specifications for School Quality}

If there is too little independent variation in our three measures of school quality, including all of them simultaneously may introduce problems with multicollinearity. This is a potential concern in our Census analysis given the weak estimated effects for each measure. To address this concern, we present estimates for the effects of education and school quality when we include: (i) each measure of quality separately and (ii) a common factor for the three measures of quality 54

The common factor for the measures of quality is obtained in two steps. First, we regress each school quality measure on state and time dummies, obtaining residuals from each of these regressions. Next, we use standard factor analysis to obtain a common factor from the three residuals. Hence, we refer to this measure of quality as the "common factor from residual quality measure" in Table D-1.

Table D-1 presents results parallel to those in column 3 of Table 11. OLS estimates of the effect of education are very similar regardless of how we include measures of school quality, while the IV estimates are slightly smaller when we include school quality measures separately than when they are included altogether. Estimated effects of quality are also quite similar when included individually or altogether. The estimated effect of our common factor from all three quality measures is economically and statistically insignificant.

\section{D.2 Additional Results}

Table D-2 reports the estimated 'reduced form' effects of compulsory schooling laws on the probability of incarceration separately for white and black women (based on equation (3) omitting school quality measures). The estimates are reported in percentage terms (i.e. coefficients multiplied by 100).

Table D-3 reports estimated effects of educational attainment and school quality by marital status and when conditioning on marital status. See Appendix $\mathrm{C}$ and footnote 39 in the text for details on the selection correction approach used in middle columns. Table D-4 reports results for the estimated probit equations for marriage used to calculate propensity scores $\hat{P}$ included in the control functions for Tables 12 and D-3.

Table D-5 reports OLS estimates of the effect of average years of completed schooling on $\log$ arrest rates for detailed offense types. Estimated effects are strongest (and statistically

\footnotetext{
${ }^{54}$ Multicollinearity of our quality measures is not a concern with our arrest rate analysis using UCR data, since all three quality measures are statistically significant. See Table 14.
} 
significant) for murder, assault, motor vehicle theft and embezzlement. Columns 1 and 2 suggest that education significantly increases arrest rates for forgery.

Table D-6 reports IV estimated effects of schooling attainment and school quality separately for violent, property and white collar crimes. These results are based on a single IV regression of interactions between indicators for broad offense type (violent, property, white collar) and the following: years of schooling, pupil/teacher ratio, term length, and relative teacher wage. Compulsory schooling laws interacted with indicators for broad offense type are used as instruments for years of schooling interacted with broad offense type.

Tables D-7 and D-8 report estimated effects of schooling on male incarceration and arrests, respectively, analogous to those reported in Tables 10 and 13 . In Table 13, we also include arrests for rape (a violent offense); these arrests are not included in our analysis of women. We do not report male results controlling for school quality measures, since the first-stage effects of compulsory schooling laws on completed schooling are much weaker for white men. For example, F-statistics are around 10 for specifications reported in columns 1 and 2 of Table 11 and much lower for specifications reported in columns 3-5 of the table. We note that the specifications for arrests (Table D-8) differ from those in Lochner and Moretti (2004) in that they include observations for white collar crimes (forgery, fraud, and embezzlement), which reduces the estimated impacts in Panel A. We also construct our compulsory schooling law instrument in a slightly different way, as discussed in Section 4 (see footnote 22 in particular). 
Table D-1: Effect of Education and School Quality on Imprisonment for White Women (in Percentage Terms)

\begin{tabular}{|c|c|c|c|c|}
\hline & $(1)$ & $(2)$ & $(3)$ & $(4)$ \\
\hline \multicolumn{5}{|l|}{ A. OLS Estimates } \\
\hline Years of education & $\begin{array}{r}-0.006^{* *} \\
(0.000)\end{array}$ & $\begin{array}{c}-0.006^{* *} \\
(0.000)\end{array}$ & $\begin{array}{c}-0.006^{* *} \\
(0.000)\end{array}$ & $\begin{array}{r}-0.006^{* *} \\
(0.000)\end{array}$ \\
\hline Pupil/Teacher ratio (10's of students) & $\begin{array}{c}0.011 \\
(0.007)\end{array}$ & & & \\
\hline Term length (100's of days) & & $\begin{array}{l}-0.021 \\
(0.023)\end{array}$ & & \\
\hline Relative teacher wage & & & $\begin{array}{c}0.005 \\
(0.008)\end{array}$ & \\
\hline Common factor from residual quality measures & & & & $\begin{array}{c}-0.002 \\
(0.002)\end{array}$ \\
\hline \multicolumn{5}{|l|}{ B. IV Estimates } \\
\hline Years of education & $\begin{array}{l}-0.051^{*} \\
(0.027)\end{array}$ & $\begin{array}{c}-0.060^{* *} \\
(0.026)\end{array}$ & $\begin{array}{c}-0.069^{* *} \\
(0.029)\end{array}$ & $\begin{array}{r}-0.071^{* *} \\
(0.029)\end{array}$ \\
\hline Pupil/Teacher ratio (10's of students) & $\begin{array}{l}-0.004 \\
(0.012)\end{array}$ & & & \\
\hline Term length (100's of days) & & $\begin{array}{c}0.026 \\
(0.033)\end{array}$ & & \\
\hline Relative teacher wage & & & $\begin{array}{c}0.031 \\
(0.015)\end{array}$ & \\
\hline Common factor from residual quality measures & & & & $\begin{array}{c}0.003 \\
(0.003)\end{array}$ \\
\hline \multicolumn{5}{|l|}{ First Stage } \\
\hline Compulsory attendance $=9$ & $\begin{array}{l}0.039^{* *} \\
(0.018)\end{array}$ & $\begin{array}{c}0.026 \\
(0.017)\end{array}$ & $\begin{array}{l}0.028^{*} \\
(0.016)\end{array}$ & $\begin{array}{c}0.011 \\
(0.017)\end{array}$ \\
\hline Compulsory attendance $=10$ & $\begin{array}{l}0.100^{* *} \\
(0.023)\end{array}$ & $\begin{array}{l}0.094^{* *} \\
(0.022)\end{array}$ & $\begin{array}{l}0.083^{* *} \\
(0.022)\end{array}$ & $\begin{array}{l}0.084^{* *} \\
(0.022)\end{array}$ \\
\hline Compulsory attendance $\geq 11$ & $\begin{array}{l}0.138^{* *} \\
(0.022)\end{array}$ & $\begin{array}{l}0.139^{* *} \\
(0.022)\end{array}$ & $\begin{array}{l}0.127^{* *} \\
(0.021)\end{array}$ & $\begin{array}{l}0.119^{* *} \\
(0.021)\end{array}$ \\
\hline F-statistic for excluded instruments & 14.77 & 16.95 & 14.40 & 14.41 \\
\hline
\end{tabular}

Notes: All regressions include dummies for state of residence, dummies for state of birth (excluding Alaska and Hawaii), dummies for age groups (age 20-22, 23-25, .., 56-58, and 59-60), dummies for decade of birth (1914-1923, 1924-1933, ..., 1964-1974), dummies for census year, state-of-residence $\times$ year effects, and state-of-residence $\times$ age. Using factor analysis, the "Common factor from residual quality measure" reflects a normalized factor score (with mean zero and variance of one) based on the residuals obtained from regressions of each school quality measure on year and state dummies. The estimated factor loadings for the residuals of pupil/teacher ratio, term length, and relative teacher wage are $-0.609,0.756$, and 0.197 , respectively, and the variances of the uniquenesses of these residuals are $0.629,0.429$, and 0.961 , respectively. Standard errors corrected for state of birth-year of birth clustering are in parentheses. ${ }^{* *}$ p-value $<0.05 .{ }^{*}$ p-value $<0.10$. 
Table D-2: Effects of Compulsory Schooling Laws on Imprisonment (in Percentage Terms)

\begin{tabular}{lccccc}
\hline \hline & $(1)$ & $(2)$ & $(3)$ & $(4)$ & $(5)$ \\
\hline A. White Females & & & & & \\
Compulsory attendance $=9$ & 0.003 & 0.002 & 0.004 & 0.002 & 0.003 \\
& $(0.003)$ & $(0.003)$ & $(0.003)$ & $(0.003)$ & $(0.003)$ \\
Compulsory attendance $=10$ & -0.004 & -0.005 & -0.003 & -0.004 & -0.002 \\
& $(0.004)$ & $(0.003)$ & $(0.004)$ & $(0.004)$ & $(0.003)$ \\
Compulsory attendance $\geq 11$ & $-0.011^{* *}$ & $-0.011^{* *}$ & $-0.008^{* *}$ & $-0.008^{* *}$ & $-0.007^{*}$ \\
& $(0.003)$ & $(0.003)$ & $(0.004)$ & $(0.004)$ & $(0.003)$ \\
F-statistic for no CSL effects & 6.64 & 5.41 & 3.72 & 3.24 & 2.98 \\
(p-value) & $(0.00)$ & $(0.00)$ & $(0.01)$ & $(0.02)$ & $(0.03)$ \\
& & & & & \\
B. Black Females & & & & & \\
Compulsory attendance $=9$ & -0.027 & -0.025 & -0.007 & -0.013 & -0.012 \\
& $(0.018)$ & $(0.018)$ & $(0.019)$ & $(0.019)$ & $(0.019)$ \\
Compulsory attendance $=10$ & -0.033 & -0.035 & -0.025 & -0.025 & -0.022 \\
& $(0.024)$ & $(0.024)$ & $(0.025)$ & $(0.025)$ & $(0.025)$ \\
Compulsory attendance $\geq 11$ & -0.044 & -0.038 & -0.039 & -0.041 & -0.020 \\
& $(0.029)$ & $(0.028)$ & $(0.029)$ & $(0.030)$ & $(0.030)$ \\
F-statistic for no CSL effects & 1.04 & 0.95 & 0.81 & 0.70 & 0.29 \\
(p-value) & $(0.37)$ & $(0.42)$ & $(0.49)$ & $(0.55)$ & $(0.83)$ \\
& & & & & $\mathrm{y}$ \\
Additional controls: & & & & & $\mathrm{y}$ \\
State of residence $\times$ year effects & & $\mathrm{y}$ & $\mathrm{y}$ & $\mathrm{y}$ & \\
State of residence $\times$ age & & & & & $\mathrm{y}$ \\
State of residence $\times$ broad age group & & & & & \\
Region of birth $\times$ cohort trend & & & & & \\
\hline
\end{tabular}

Notes: All regressions include dummies for state of residence, dummies for state of birth (excluding Alaska and Hawaii), dummies for age groups (age 20-22, 23-25, .., 56-58, and 59-60), dummies for decade of birth (1914-1923, 1924-1933, ..., 1964-1974), and dummies for census year. The regressions for black females also include state-of-birth dummies interacted with a dummy for black women born in the South who turn age 14 in 1958 or later to account for the impact of Brown v. Board of Education. "broad age group" reflects three dummies for the following age groups: 20-34, 35-49, and 50-64. F-stastics are reported for tests of zero effects of all three compulsory attendance measures. The sample size for white females is $3,613,313$ and for black females is 480,709. Standard errors corrected for state of birth-year of birth clustering are in parentheses. ${ }^{* *}$ p-value $<0.05$. ${ }^{*}$ p-value $<0.10$. 
Table D-3: Effects of Education, School Quality, and Marriage on Incarceration for White Women (in Percentage Terms)

\begin{tabular}{|c|c|c|c|c|c|c|}
\hline & \multicolumn{2}{|c|}{ No Selection Correction } & \multicolumn{2}{|c|}{$\overline{\text { Selection Correction }}$} & \multirow{2}{*}{\multicolumn{2}{|c|}{$\begin{array}{l}\text { Control for Marriage } \\
\text { and Education }\end{array}$}} \\
\hline & Married & Single & Married & Single & & \\
\hline \multicolumn{7}{|l|}{ A. IV Estimates } \\
\hline Years of education & $\begin{array}{c}-0.052^{* *} \\
(0.026)\end{array}$ & $\begin{array}{l}-0.165^{*} \\
(0.086)\end{array}$ & $\begin{array}{c}-0.033^{* *} \\
(0.016)\end{array}$ & $\begin{array}{l}-0.079 \\
(0.077)\end{array}$ & \multicolumn{2}{|c|}{$\begin{array}{c}-0.041^{*} \\
(0.025)\end{array}$} \\
\hline Married & & & & & \multicolumn{2}{|c|}{$\begin{array}{l}-0.111 \\
(0.195)\end{array}$} \\
\hline $\begin{array}{l}\text { Pupil/Teacher ratio } \\
\text { (10's of students) }\end{array}$ & $\begin{array}{l}-0.012 \\
(0.010)\end{array}$ & $\begin{array}{l}-0.007 \\
(0.035)\end{array}$ & $\begin{array}{l}-0.011 \\
(0.009)\end{array}$ & $\begin{array}{c}0.012 \\
(0.046)\end{array}$ & \multicolumn{2}{|c|}{$\begin{array}{l}-0.001 \\
(0.013)\end{array}$} \\
\hline $\begin{array}{l}\text { Term length } \\
\text { (100's of days) }\end{array}$ & $\begin{array}{l}-0.011 \\
(0.021)\end{array}$ & $\begin{array}{c}0.074 \\
(0.085)\end{array}$ & $\begin{array}{l}-0.018 \\
(0.020)\end{array}$ & $\begin{array}{c}0.100 \\
(0.086)\end{array}$ & \multicolumn{2}{|c|}{$\begin{array}{l}-0.008 \\
(0.026)\end{array}$} \\
\hline Relative teacher wage & $\begin{array}{l}0.022^{*} \\
(0.013)\end{array}$ & $\begin{array}{c}0.094^{*} \\
(0.051)\end{array}$ & $\begin{array}{c}0.011 \\
(0.008)\end{array}$ & $\begin{array}{c}0.060 \\
(0.037)\end{array}$ & \multicolumn{2}{|c|}{$\begin{array}{l}0.025^{*} \\
(0.013)\end{array}$} \\
\hline \multicolumn{7}{|l|}{ B. First-stage estimates } \\
\hline Compulsory attend. $=9$ & $\begin{array}{c}0.005 \\
(0.017)\end{array}$ & $\begin{array}{l}-0.017 \\
(0.028)\end{array}$ & $\begin{array}{c}0.008 \\
(0.016)\end{array}$ & $\begin{array}{l}-0.016 \\
(0.028)\end{array}$ & $\frac{\text { Education }}{0.001}$ & $\frac{\text { Married }}{-0.000}$ \\
\hline Compulsory attend. $=10$ & $\begin{array}{l}0.057^{* *} \\
(0.022)\end{array}$ & $\begin{array}{l}0.097^{* *} \\
(0.037)\end{array}$ & $\begin{array}{l}0.055^{* *} \\
(0.022)\end{array}$ & $\begin{array}{l}0.108^{* *} \\
(0.035)\end{array}$ & $\begin{array}{l}0.070^{* *} \\
(0.022)\end{array}$ & $\begin{array}{c}0.001 \\
(0.003)\end{array}$ \\
\hline Compulsory attend. $\geq 11$ & $\begin{array}{l}0.092^{* *} \\
(0.022)\end{array}$ & $\begin{array}{l}0.114^{* *} \\
(0.032)\end{array}$ & $\begin{array}{l}0.037^{*} \\
(0.022)\end{array}$ & $\begin{array}{c}0.050 \\
(0.032)\end{array}$ & $\begin{array}{l}0.092^{* *} \\
(0.021)\end{array}$ & $\begin{array}{l}0.008^{* *} \\
(0.003)\end{array}$ \\
\hline Quarter of birth 2 & & & $\begin{array}{c}-0.039^{* *} \\
(0.008)\end{array}$ & $\begin{array}{l}-0.006 \\
(0.014)\end{array}$ & $\begin{array}{c}0.007 \\
(0.005)\end{array}$ & $\begin{array}{l}0.009^{* *} \\
(0.001)\end{array}$ \\
\hline Quarter of birth 3 & & & $\begin{array}{c}0.003 \\
(0.008)\end{array}$ & $\begin{array}{c}0.020 \\
(0.014)\end{array}$ & $\begin{array}{l}0.046^{* *} \\
(0.004)\end{array}$ & $\begin{array}{l}0.009^{* *} \\
(0.001)\end{array}$ \\
\hline Quarter of birth 4 & & & $\begin{array}{l}0.049^{* *} \\
(0.006)\end{array}$ & $\begin{array}{l}0.049^{* *} \\
(0.010)\end{array}$ & $\begin{array}{l}0.064^{* *} \\
(0.004)\end{array}$ & $\begin{array}{l}0.004^{* *} \\
(0.001)\end{array}$ \\
\hline F-stat. for excl. instr. & 8.83 & 8.11 & 41.68 & 10.05 & 49.05 & 24.53 \\
\hline Observations & $2,603,443$ & 892,346 & $2,603,443$ & 892,346 & $3,495,789$ & $3,495,789$ \\
\hline
\end{tabular}

Notes: All regressions include dummies for state of residence, dummies for state of birth (excluding Alaska and Hawaii), dummies for age groups (age 20-22, 23-25, .., 56-58, and 59-60), dummies for decade of birth (1914-1923, 1924-1933, ..., 1964-1974), dummies for census year, state-of-residence $\times$ year effects, and state-ofresidence $\times$ age. For "Married" specifications, the dependent variable is a dummy equal to one if the respondent is married, and zero if not. For the "Single" specifications, the dependent variable is a dummy equal to one if the respondent is married, and zero if not. The specifications with "No Selection Correction" split the sample in married and single women and estimates the effect of schooling on incarceration by 2SLS. The specifications with "Selection Correction" split the sample in married and single women and estimates the effect of schooling on incarceration by 2SLS and a control function as described in Appendix C. Standard errors corrected for state of birth-year of birth clustering are in parentheses. ${ }^{* *}$ p-value $<0.05 .{ }^{*}$ p-value $<0.10$. 
Table D-4: Probit Equations for being Unmarried

\begin{tabular}{|c|c|c|}
\hline & (1) & $(2)$ \\
\hline Compulsory attendance $=9($ at age 14$)$ & $\begin{array}{c}-0.008^{*} \\
(0.004)\end{array}$ & $\begin{array}{l}-0.001 \\
(0.004)\end{array}$ \\
\hline Compulsory attendance $=10($ at age 14$)$ & $\begin{array}{c}-0.017^{* *} \\
(0.005)\end{array}$ & $\begin{array}{l}-0.007 \\
(0.005)\end{array}$ \\
\hline Compulsory attendance $\geq 11$ (at age 14$)$ & $\begin{array}{c}-0.034^{* *} \\
(0.005)\end{array}$ & $\begin{array}{c}-0.020^{* *} \\
(0.006)\end{array}$ \\
\hline Compulsory attendance $=9($ at age 10$)$ & $\begin{array}{c}-0.008^{*} \\
(0.004)\end{array}$ & $\begin{array}{c}0.002 \\
(0.004)\end{array}$ \\
\hline Compulsory attendance $=10($ at age 10$)$ & $\begin{array}{c}0.000 \\
(0.005)\end{array}$ & $\begin{array}{c}0.000 \\
(0.005)\end{array}$ \\
\hline Compulsory attendance $\geq 11$ (at age 10$)$ & $\begin{array}{l}-0.006 \\
(0.005)\end{array}$ & $\begin{array}{c}-0.002 \\
(0.005)\end{array}$ \\
\hline Quarter of birth 2 & $\begin{array}{c}-0.032^{* *} \\
(0.002)\end{array}$ & $\begin{array}{c}-0.027^{* *} \\
(0.002)\end{array}$ \\
\hline Quarter of birth 3 & $\begin{array}{c}-0.032^{* *} \\
(0.002)\end{array}$ & $\begin{array}{c}-0.027^{* *} \\
(0.002)\end{array}$ \\
\hline Quarter of birth 4 & $\begin{array}{c}-0.014^{* *} \\
(0.002)\end{array}$ & $\begin{array}{c}-0.011^{* *} \\
(0.002)\end{array}$ \\
\hline Pupil/Teacher ratio (10's of students) & & $\begin{array}{c}-0.023^{* *} \\
(0.007)\end{array}$ \\
\hline Term length (100's of days) & & $\begin{array}{c}-0.190^{* *} \\
(0.025)\end{array}$ \\
\hline Relative teacher wage & & $\begin{array}{c}-0.074^{* *} \\
(0.010)\end{array}$ \\
\hline Observations & $3,587,873$ & $3,495,789$ \\
\hline
\end{tabular}

Notes: The dependent variable is a dummy equal to one if the woman is single and zero if the woman is married. Both probit regressions include dummies for state of residence, dummies for state of birth (excluding Alaska and Hawaii), dummies for age groups (age 20-22, 23-25, .., 5658 , and 59-60), dummies for decade of birth (1914-1923, 1924-1933, ..., 1964-1974), dummies for census year, state-of-residence $\times$ year effects, and state-of-residence $\times$ age. ${ }^{* *}$ p-value $<0.05 .{ }^{*}$ p-value $<0.10$. 
Table D-5: OLS Estimates of the Effect of Education on Log Arrest Rates for Detailed Offense Types

\begin{tabular}{|c|c|c|c|}
\hline & $(1)$ & $(2)$ & $(3)$ \\
\hline \multicolumn{4}{|l|}{ A. Violent offenses only } \\
\hline Murder & $\begin{array}{c}-0.420^{* *} \\
(0.093)\end{array}$ & $\begin{array}{c}-0.378^{* *} \\
(0.099)\end{array}$ & $\begin{array}{c}-0.356^{* *} \\
(0.112)\end{array}$ \\
\hline Robbery & $\begin{array}{c}0.004 \\
(0.108)\end{array}$ & $\begin{array}{c}-0.090 \\
(0.123)\end{array}$ & $\begin{array}{c}-0.101 \\
(0.119)\end{array}$ \\
\hline Assault & $\begin{array}{c}-0.419^{* *} \\
(0.076)\end{array}$ & $\begin{array}{c}-0.402^{* *} \\
(0.074)\end{array}$ & $\begin{array}{c}-0.404^{* *} \\
(0.100)\end{array}$ \\
\hline \multicolumn{4}{|l|}{ B. Property offenses only } \\
\hline Burglary & $\begin{array}{c}-0.014 \\
(0.089)\end{array}$ & $\begin{array}{c}0.056 \\
(0.092)\end{array}$ & $\begin{array}{l}0.168^{*} \\
(0.099)\end{array}$ \\
\hline Larceny & $\begin{array}{c}0.003 \\
(0.068)\end{array}$ & $\begin{array}{c}0.009 \\
(0.067)\end{array}$ & $\begin{array}{c}0.117 \\
(0.084)\end{array}$ \\
\hline Vehicle theft & $\begin{array}{c}-0.381^{* *} \\
(0.126)\end{array}$ & $\begin{array}{c}-0.373^{* *} \\
(0.141)\end{array}$ & $\begin{array}{c}-0.300^{* *} \\
(0.127)\end{array}$ \\
\hline Arson & $\begin{array}{l}-0.083 \\
(0.130)\end{array}$ & $\begin{array}{l}-0.087 \\
(0.133)\end{array}$ & $\begin{array}{c}0.006 \\
(0.126)\end{array}$ \\
\hline \multicolumn{4}{|l|}{ C. White collar offenses only } \\
\hline Forgery & $\begin{array}{l}0.178^{* *} \\
(0.083)\end{array}$ & $\begin{array}{l}0.215^{* *} \\
(0.076)\end{array}$ & $\begin{array}{c}0.104 \\
(0.096)\end{array}$ \\
\hline Fraud & $\begin{array}{c}0.046 \\
(0.072)\end{array}$ & $\begin{array}{c}0.016 \\
(0.062)\end{array}$ & $\begin{array}{l}-0.101 \\
(0.085)\end{array}$ \\
\hline Embezzlement & $\begin{array}{c}-0.489^{* *} \\
(0.122)\end{array}$ & $\begin{array}{c}-0.412^{* *} \\
(0.121)\end{array}$ & $\begin{array}{c}-0.525^{* *} \\
(0.139)\end{array}$ \\
\hline \multicolumn{4}{|l|}{ Controls: } \\
\hline age $\times$ offense effects & $\mathrm{y}$ & $\mathrm{y}$ & $\mathrm{y}$ \\
\hline offense $\times$ year effects & $\mathrm{y}$ & $\mathrm{y}$ & $\mathrm{y}$ \\
\hline age $\times$ year effects & $\mathrm{y}$ & $\mathrm{y}$ & $\mathrm{y}$ \\
\hline state $\times$ year & $\mathrm{y}$ & $\mathrm{y}$ & $\mathrm{y}$ \\
\hline state $\times$ offense effects & $\mathrm{y}$ & $\mathrm{y}$ & $\mathrm{y}$ \\
\hline $\begin{array}{l}\text { state } \times \text { offense } \times \text { year effects } \\
\text { state } \times \text { broad age group }\end{array}$ & & $\mathrm{y}$ & $\begin{array}{l}\mathrm{y} \\
\mathrm{y}\end{array}$ \\
\hline
\end{tabular}

Notes: The dependent variable is the logarithm of the arrest rate by age, type of offense, state, and year. Average schooling is by age group, state, and year. All models control for the percentage black. There are eight age groups: 20-24, 25-29, 30-34, 35-39, 40$44,45-49,50-54$, and 55-59. There are 50 states plus the District of Columbia and four years 1960, 1970, 1980, and 1990. All models are weighted by cell size calculated as the number of women in each cell from the Census. Standard errors for state-year-age clustering are in parentheses. ${ }^{* *}$ p-value $<0.05$. ${ }^{*}$ p-value $<0.10$. 
Table D-6: IV Estimates of the Effects of Education and School Quality on Log Arrest Rates by Broad Offense Type

\begin{tabular}{lccc}
\hline \hline & Violent crime & Property crime & White collar crime \\
\hline Years of education & $-0.521^{*}$ & $-0.789^{* *}$ & 0.085 \\
& $(0.273)$ & $(0.310)$ & $(0.244)$ \\
Pupil/Teacher ratio (10's of students) & $-0.855^{* *}$ & $-0.821^{* *}$ & $-0.652^{* *}$ \\
& $(0.263)$ & $(0.257)$ & $(0.273)$ \\
Term length (100's of days) & $-1.848^{* *}$ & -0.778 & $-1.275^{*}$ \\
Relative teacher wage & $(0.635)$ & $(0.683)$ & $(0.730)$ \\
& -0.369 & $-0.874^{* *}$ & -0.169 \\
& $(0.225)$ & $(0.205)$ & $(0.264)$ \\
\hline
\end{tabular}

Notes: This table reports estimated effects (from a single IV regression) of interactions between indicators for broad offense type (violent, property, white collar) and the following: years of schooling, pupil/teacher ratio, term length, and relative teacher wage. Compulsory schooling laws interacted with indicators for broad offense type are used as instruments for years of schooling interacted with broad offense type. Other controls include age $\times$ offense effects, offense $\times$ year effects, age $\times$ year effects, state $\times$ year, state $\times$ offense effects, state $\times$ offense, and state $\times$ offense $\times$ year effects. Standard errors for state-year-age clustering are in parentheses. ${ }^{* *}$ p-value $<0.05 .{ }^{*}$ p-value $<0.10$. 
Table D-7: Effect of Years of Education on Imprisonment for Males (in Percentage Terms)

\begin{tabular}{|c|c|c|c|c|c|}
\hline & $(1)$ & $(2)$ & $(3)$ & $(4)$ & $(5)$ \\
\hline $\begin{array}{l}\text { A. White Males } \\
\text { OLS estimates }\end{array}$ & $\begin{array}{c}-0.092^{* *} \\
(0.003)\end{array}$ & $\begin{array}{c}-0.093^{* *} \\
(0.003)\end{array}$ & $\begin{array}{c}-0.093^{* *} \\
(0.003)\end{array}$ & $\begin{array}{c}-0.093^{* *} \\
(0.003)\end{array}$ & $\begin{array}{c}-0.093^{* *} \\
(0.003)\end{array}$ \\
\hline IV estimates & $\begin{array}{l}-0.063 \\
(0.055)\end{array}$ & $\begin{array}{c}-0.118^{* *} \\
(0.060)\end{array}$ & $\begin{array}{l}-0.212^{*} \\
(0.111)\end{array}$ & $\begin{array}{c}-0.197^{* *} \\
(0.096)\end{array}$ & $\begin{array}{c}-0.284^{* *} \\
(0.121)\end{array}$ \\
\hline \multicolumn{6}{|l|}{ First-Stage: } \\
\hline Compulsory attendance $=9$ & $\begin{array}{l}0.222^{* *} \\
(0.025)\end{array}$ & $\begin{array}{l}0.202^{* *} \\
(0.025)\end{array}$ & $\begin{array}{l}0.117^{* *} \\
(0.023)\end{array}$ & $\begin{array}{l}0.125^{* *} \\
(0.024)\end{array}$ & $\begin{array}{l}0.080^{* *} \\
(0.018)\end{array}$ \\
\hline Compulsory attendance $=10$ & $\begin{array}{l}0.207^{* *} \\
(0.035)\end{array}$ & $\begin{array}{l}0.183^{* *} \\
(0.034)\end{array}$ & $\begin{array}{l}0.092^{* *} \\
(0.031)\end{array}$ & $\begin{array}{l}0.119^{* *} \\
(0.033)\end{array}$ & $\begin{array}{c}0.007 \\
(0.025)\end{array}$ \\
\hline Compulsory attendance $\geq 11$ & $\begin{array}{l}0.341^{* *} \\
(0.034)\end{array}$ & $\begin{array}{l}0.331^{* *} \\
(0.034)\end{array}$ & $\begin{array}{l}0.177^{* *} \\
(0.030)\end{array}$ & $\begin{array}{l}0.216^{* *} \\
(0.032)\end{array}$ & $\begin{array}{l}0.131^{* *} \\
(0.025)\end{array}$ \\
\hline F-statistic for excluded instruments & 36.90 & 34.42 & 13.30 & 16.00 & 12.96 \\
\hline \multicolumn{6}{|l|}{ B. Black Males } \\
\hline OLS estimates & $\begin{array}{c}-0.362^{* *} \\
(0.014)\end{array}$ & $\begin{array}{c}-0.364^{* *} \\
(0.015)\end{array}$ & $\begin{array}{c}-0.365^{* *} \\
(0.015)\end{array}$ & $\begin{array}{c}-0.365^{* *} \\
(0.015)\end{array}$ & $\begin{array}{c}-0.364^{* *} \\
(0.015)\end{array}$ \\
\hline IV estimates & $\begin{array}{l}-0.335^{*} \\
(0.185)\end{array}$ & $\begin{array}{c}-0.412^{* *} \\
(0.199)\end{array}$ & $\begin{array}{l}-0.488 \\
(0.318)\end{array}$ & $\begin{array}{c}-0.591^{* *} \\
(0.281)\end{array}$ & $\begin{array}{l}-0.373 \\
(0.476)\end{array}$ \\
\hline \multicolumn{6}{|l|}{ First-Stage: } \\
\hline Compulsory attendance $=9$ & $\begin{array}{l}0.455^{* *} \\
(0.041)\end{array}$ & $\begin{array}{l}0.423^{* *} \\
(0.040)\end{array}$ & $\begin{array}{l}0.281^{* *} \\
(0.034)\end{array}$ & $\begin{array}{l}0.311^{* *} \\
(0.034)\end{array}$ & $\begin{array}{l}0.189^{* *} \\
(0.032)\end{array}$ \\
\hline Compulsory attendance $=10$ & $\begin{array}{l}0.472^{* *} \\
(0.072)\end{array}$ & $\begin{array}{l}0.430^{* *} \\
(0.071)\end{array}$ & $\begin{array}{l}0.257^{* *} \\
(0.060)\end{array}$ & $\begin{array}{l}0.311^{* *} \\
(0.062)\end{array}$ & $\begin{array}{l}0.176^{* *} \\
(0.051)\end{array}$ \\
\hline Compulsory attendance $\geq 11$ & $\begin{array}{l}0.530^{* *} \\
(0.064)\end{array}$ & $\begin{array}{l}0.508^{* *} \\
(0.062)\end{array}$ & $\begin{array}{l}0.323^{* *} \\
(0.051)\end{array}$ & $\begin{array}{l}0.379^{* *} \\
(0.052)\end{array}$ & $\begin{array}{l}0.225^{* *} \\
(0.048)\end{array}$ \\
\hline F-statistic for excluded instruments & 44.77 & 41.29 & 25.40 & 31.51 & 12.36 \\
\hline \multicolumn{6}{|l|}{ Additional controls: } \\
\hline State of residence $\times$ year effects & & $\mathrm{y}$ & $\mathrm{y}$ & $\mathrm{y}$ & $\mathrm{y}$ \\
\hline State of residence $\times$ age & & & $\mathrm{y}$ & & \\
\hline $\begin{array}{l}\text { State of residence } \times \text { broad age group } \\
\text { Region of birth } \times \text { cohort trend }\end{array}$ & & & & $\mathrm{y}$ & $\mathrm{y}$ \\
\hline
\end{tabular}

Notes: All regressions include dummies for state of residence, dummies for state of birth (excluding Alaska and Hawaii), dummies for age groups (age 20-22, 23-25, ..., 56-58, and 59-60), dummies for decade of birth (1914-1923, 1924-1933, ..., 1964-1974), and dummies for census year. The regressions for black males also include state-of-birth dummies interacted with a dummy for black men born in the South who turn age 14 in 1958 or later to account for the impact of Brown v. Board of Education. "broad age group" reflects three dummies for the following age groups: 20-34, 35-49, and 50-64. The F-test for excluded instruments for white males is distributed $F_{(3,2988)}$ and for black males is distributed $F_{(3,2576)}$. The sample size for white males is $3,502,386$ and for black males is 401,453 . Standard errors corrected for state of birth-year of birth clustering are in parentheses. ${ }^{* *}$ p-value $<0.05$. ${ }^{*}$ p-value $<0.10$. 
Table D-8: Effects of Average Schooling on Log Arrest Rates for Males

\begin{tabular}{|c|c|c|c|c|c|c|}
\hline & \multicolumn{3}{|c|}{ OLS Estimates } & \multicolumn{3}{|c|}{ IV Estimates } \\
\hline & $(1)$ & $(2)$ & $(3)$ & $(4)$ & $(5)$ & (6) \\
\hline A. All Offenses & $\begin{array}{l}-0.033 \\
(0.025)\end{array}$ & $\begin{array}{l}-0.027 \\
(0.026)\end{array}$ & $\begin{array}{c}-0.132^{* *} \\
(0.030)\end{array}$ & $\begin{array}{c}-0.054 \\
(0.058)\end{array}$ & $\begin{array}{l}-0.053 \\
(0.058)\end{array}$ & $\begin{array}{c}-0.280^{* *} \\
(0.141)\end{array}$ \\
\hline \multicolumn{7}{|l|}{ First Stage } \\
\hline Compulsory attendance $=9$ & & & & $\begin{array}{c}0.596^{* *} \\
(0.076)\end{array}$ & $\begin{array}{l}0.598^{* *} \\
(0.081)\end{array}$ & $\begin{array}{l}0.265^{* *} \\
(0.052)\end{array}$ \\
\hline Compulsory attendance $=10$ & & & & $\begin{array}{c}0.551^{* *} \\
(0.090)\end{array}$ & $\begin{array}{l}0.553^{* *} \\
(0.095)\end{array}$ & $\begin{array}{l}0.207^{* *} \\
(0.061)\end{array}$ \\
\hline Compulsory attendance $\geq 11$ & & & & $\begin{array}{l}0.738^{* *} \\
(0.111)\end{array}$ & $\begin{array}{l}0.739^{* *} \\
(0.117)\end{array}$ & $\begin{array}{l}0.248^{* *} \\
(0.073)\end{array}$ \\
\hline F-statistic for excluded instruments & & & & 22.01 & 19.88 & 9.87 \\
\hline \multicolumn{7}{|l|}{ B. Effects by Broad Offense Type } \\
\hline Violent crime & $\begin{array}{l}-0.053^{*} \\
(0.028)\end{array}$ & $\begin{array}{l}-0.017 \\
(0.028)\end{array}$ & $\begin{array}{c}-0.123^{* *} \\
(0.032)\end{array}$ & $\begin{array}{l}-0.116^{*} \\
(0.065)\end{array}$ & $\begin{array}{l}-0.040 \\
(0.065)\end{array}$ & $\begin{array}{c}-0.274^{*} \\
(0.145)\end{array}$ \\
\hline Property crime & $\begin{array}{l}-0.046 \\
(0.031)\end{array}$ & $\begin{array}{c}-0.024 \\
(0.031)\end{array}$ & $\begin{array}{c}-0.129^{* *} \\
(0.033)\end{array}$ & $\begin{array}{l}-0.100 \\
(0.071)\end{array}$ & $\begin{array}{c}-0.092 \\
(0.073)\end{array}$ & $\begin{array}{c}-0.320^{* *} \\
(0.142)\end{array}$ \\
\hline White collar crime & $\begin{array}{c}0.015 \\
(0.032)\end{array}$ & $\begin{array}{l}-0.044 \\
(0.028)\end{array}$ & $\begin{array}{c}-0.149^{* *} \\
(0.034)\end{array}$ & $\begin{array}{c}0.103 \\
(0.075)\end{array}$ & $\begin{array}{l}-0.013 \\
(0.057)\end{array}$ & $\begin{array}{l}-0.232 \\
(0.147)\end{array}$ \\
\hline \multicolumn{7}{|l|}{ Controls: } \\
\hline age $\times$ offense effects & $\mathrm{y}$ & $\mathrm{y}$ & $\mathrm{y}$ & $\mathrm{y}$ & $\mathrm{y}$ & $\mathrm{y}$ \\
\hline offense $\times$ year effects & $\mathrm{y}$ & $\mathrm{y}$ & $\mathrm{y}$ & $\mathrm{y}$ & $\mathrm{y}$ & $\mathrm{y}$ \\
\hline age $\times$ year effects & $\mathrm{y}$ & $\mathrm{y}$ & $\mathrm{y}$ & $\mathrm{y}$ & $\mathrm{y}$ & $\mathrm{y}$ \\
\hline state $\times$ year & $\mathrm{y}$ & $\mathrm{y}$ & $\mathrm{y}$ & $\mathrm{y}$ & $\mathrm{y}$ & $\mathrm{y}$ \\
\hline state $\times$ offense effects & $\mathrm{y}$ & $\mathrm{y}$ & $\mathrm{y}$ & $\mathrm{y}$ & $\mathrm{y}$ & $\mathrm{y}$ \\
\hline state $\times$ offense $\times$ year effects & & $\mathrm{y}$ & $\mathrm{y}$ & & $\mathrm{y}$ & $\mathrm{y}$ \\
\hline state $\times$ broad age group & & & $\mathrm{y}$ & & & $\mathrm{y}$ \\
\hline
\end{tabular}

Notes: The dependent variable is the logarithm of the arrest rate by age, type of offense, state, and year. Average schooling is by age group, state, and year. All models control for the percentage black. There are eight age groups: 20-24, 25-29, 30-34, 35-39, 40-44, 45-49, 50-54, and 55-59. There are 50 states plus the District of Columbia and four years 1960, 1970, 1980, and 1990. All models are weighted by cell size calculated as the number of men in each cell from the Census. The F-test for excluded instruments is distributed $F_{(3,1452)}$. Standard errors for state-year-age clustering are in parentheses. ${ }^{* *}$ p-value $<0.05$. ${ }^{*}$ p-value $<0.10$. 